\author{
SERIES "RECENT DEVELOPMENTS IN PULMONARY INFECTIONS" \\ Edited by M. Woodhead and T. Schaberg \\ Number 5 in this Series
}

\title{
M. tuberculosis: immunology and vaccination
}

\author{
G.A.W. Rook, G. Seah, A. Ustianowski
}

M. tuberculosis: Immunology and vaccination. G.A.W. Rook, G. Seah, A. Ustianowski. (C) ERS Journals Ltd 2001.

ABSTRACT: Tuberculosis is increasing. Current treatment regimens require at least 6 months, because latent or stationary phase organisms are difficult to kill. Such regimens do not achieve full compliance, and "directly observed therapy short course" (DOTS) is having less impact than expected. This worrying situation is aggravated by coinfection with human immunodeficiency virus (HIV), and by the increase in drug-resistant strains.

We need new insights that lead to more rapid therapies and immunotherapies, and more reliable vaccines.

Recent insights have come from: understanding of the relationship between Mycobacterium tuberculosis and macrophages; the multiple $\mathbf{T}$ cell types that recognise mycobacterial peptides, lipids and glycolipids; the critical role of interferon- $\gamma$ (IFN $\gamma$ ) and interleukin-12 (IL-12) in human mycobacterial infection revealed by genetically defective children; quantitation of the presence and importance of Th2 lymphocyte activation in human tuberculosis; the role of local conversion of inactive cortisone to active cortisol in the lesions; the recognition that some effective prophylactic vaccines also work as immumotherapeutics whereas others do not. In the longer term the recent sequencing of the $M$. tuberculosis genome will lead to further advances.

In the short term, effective immunotherapy remains the most accessible breakthrough in the management of tuberculosis. The types of practical advance that will result from sequencing the genome are discussed speculatively, but cannot yet be predicted with certainty.

Eur Respir J 2001; 17: 537-557.

Dept of Bacteriology, Royal Free and University College London Medical School, Windeyer Institute of Medical Sciences, London, UK.

Correspondence: G.A.W. Rook, Dept of Bacteriology, Royal Free and University College London Medical School, Windeyer Institute of Medical Sciences, 46 Cleveland Street, London, UK.

Keywords: Cytokines

endocrinology

immunology

immunotherapy

macrophages

vaccines

Received: June 202000

Accepted after revision June 272000
Tuberculosis is a global emergency. One third of the world's population is infected, and although only about $5-10 \%$ develop active disease during the first few years following exposure [1], this still results in a massive case load, with eight million new cases each year, and three million deaths. Moreover, the percentage that progresses to disease is increasing. Tuberculosis is one of the first secondary infections to be activated in human immunodeficiency virus (HIV)-positive individuals [2]. Moreover the stresses of poverty, malnutrition and war, increase the rate of reactivation for reasons discussed later. Even in developed countries such as the United Kingdom, the disease distribution in large cities parallels the distribution of poverty [3]. Meanwhile the breakdown of healthcare systems is leading to incomplete case and contact tracing, incomplete treatment, and increases in drug resistance. In some parts of the world, many of the available drugs are fake or out of date [4]. In many areas, existing treatment is probably doing more harm than good, as incomplete treatment regimens select for drug resistance. Multidrugresistant tuberculosis is spreading at an alarming rate, and invading Western Europe from the Eastern block countries such as Estonia. There were more cases of tuberculosis in 1999 than ever before in the history of mankind.

\section{The problem of the six month treatment regimen}

An important reason for the current failure to control tuberculosis is the fact that even the best available treatment must be continued for at least 6 months. This treatment regimen is not a realistic proposition in most developing countries, or even in the inner cities of rich ones, because the patients feel well after a few weeks and stop taking the drugs. The World Health Organization (WHO) now admits that directly observed therapy short-course (DOTS), in which the

Previous articles in this series: No. 1: M.R. Hammerschlag. Chlamydia pneumoniae and the lung. Eur Respir J 2000; 16: 1001 - 1007. No. 2: S. Ewig, H. Schäfer, A. Torres. Severity assessment in community acquired pneumonia. Eur Respir J 2000; 16: 1193-1201. No. 3: L.P. Nicod, J-C. Pache, N. Howorth. Fungal infections in transplant recipients. Eur Respir J 2001; 17: 133-140. No. 4: A.M. Jones, M.E. Dodd, A.K. Webb. Burkholderia cepacia: current clinical issues, environmental controversies and ethical dilemmas. Eur Respir J 2001; 17: 295 - 301. 
patient is supervised while taking every dose of therapy, helps but does not solve the problem [5].

\section{Persistent bacilli and latent infection}

There are two interrelated reasons for the requirement for 6 month regimens. The first is obvious and often discussed. The chemotherapy kills the vast majority of the bacteria within a few days, but there are subpopulations of "persisters" [6]. It is not clear whether these organisms are in true stationary phase [7] or merely replicating extremely slowly. Nor is it clear where they are located. Most authors assume that they are in old lesions or sites of fibrosis or calcification, where oxygen availability may be low. However, in a forgotten paper published in 1927, OPIE and ARONSON [8] reported that $80 \%$ of tuberculous lesions were already sterile 5 yrs after the primary infection, whereas live bacilli could be found in macroscopically normal lung tissue. The fact that metronidazole, a drug that should be active under anaerobic conditions, is not active in a model of latent tuberculosis infection in mice, implies that live organisms also persist in welloxygenated sites in this species [9].

Not only do persister organisms cause problems for treatment, but they also constitute an important source of infection. They can persist for the rest of the life of the individual [10], and, at least in countries with low or moderate tuberculosis endemicity, many cases of tuberculosis result from reactivation of latent infection $[11-13]$.

\section{Protection versus immunopathology}

The other reason for the need for prolonged treatment is usually overlooked. Most tuberculosis patients have a necrotizing pattern of response to Mycobacterium tuberculosis, analogous to the phenomenon first noted by Косн [14] in guinea-pigs. There is overwhelming evidence that the Koch phenomenon is not a correlate of optimal protective immunity to tuberculosis. Indeed preimmunisation of animals so that they have a Koch phenomenon before they are challenged with virulent $M$. tuberculosis results in a clear and reproducible increase in susceptibility to the disease, compared to nonimmunised controls [15]. This and other aspects of the Koch phenomenon are discussed in detail later. Its relevance at this point is that this inappropriate pattern of response may not correct itself rapidly during treatment. Therefore if chemotherapy is stopped at 3 months, relapse rates are high [16] even when the chemotherapy was an optimal rifampicin-containing one that achieved sputum negativity well before 3 months, and in spite of the fact that there are very few live organisms in the patients' tissues at this time.

We therefore need to understand the differences between protective immunity and the Koch phenomenon, and the factors that determine which response pattern is present. The ultimate objective is to learn to replace the pathological response with the protective one very early during treatment.
Immunity to tuberculosis

\section{Immunity to tuberculosis in mice}

Antibody. It is generally assumed that antibodies are irrelevant to immunity to tuberculosis. This assumption is probably premature. Mice lacking B cells appeared to respond normally to the infection [17]. However, in another murine model at least one monoclonal antibody was found to be significantly protective [18]. The matter has been exhaustively reviewed and clearly needs to be reinvestigated [19]. While it is clearly true that most of the antibody formed is irrelevant, it remains probable that neutralizing antibodies to specific pharmacologically active components of the organism will prove to play an important role. Unfortunately the identification of such active components of the organism is still in its infancy.

The crucial role of Type 1 responses. The ability to manipulate the immune system of mice with neutralizing antibodies or gene knockout has provided strong evidence that in this species, immunity to tuberculosis correlates with a Type 1 response. In vivo T-helper (Th) 1 or Th2 cells act in concert with $\mathrm{CD}^{+}$cells, and with numerous other cell types including macrophages, B cells and some stromal cells. Collectively these give rise to two patterns of cytokine release known as Type 1 (dominated by interleukin-2 (IL-2), interleukin-12 (IL-12), and interferon- $\gamma(\mathrm{IFN} \gamma)$ ) and Type 2 (dominated by interleukin-(IL)-4, 5, and 13) [20, 21]. The term "Type 1 " is used in preference to Th1 when it is intended to refer to the overall pattern of cytokine release by all cell types in the infected site, rather than merely that produced by the $\mathrm{CD}^{+}$helper $\mathrm{T}$ cells that were included in the original scheme of MosmanN [22].

Disruption of the major histocompatibility complex (MHC) Class II genes or of the gene for the $\beta$ chain of the $\alpha / \beta \mathrm{T}$ cell receptor [23] resulting in a deficiency of CD4 ${ }^{+} \alpha / \beta \mathrm{T}$ cells, render mice susceptible even to the avirulent Bacillus Calmette Guérin (BCG). Disruption of the gene for IFN $\gamma$ makes mice very susceptible to $M$. tuberculosis (death within 3 weeks), and such mice may even die after many weeks from challenge with BCG [24-26]. IL-18 knockout (KO) mice are also more susceptible, perhaps because IL-18 contributes to the induction of IFN $\gamma$ expression [27]. A major inducer of the Type 1 pathway is IL-12. The exact role of this cytokine depends on the mouse strain [28], but IL$12 \mathrm{KO}$ mice are more susceptible to tuberculosis [29].

The detrimental role of Type 2 responses. These data emphasise the crucial role of the Type 1 response. In agreement with this, other data indicate that the Type 2 response is not only unable to protect mice, but can seriously undermine the efficacy of the Type 1 response. If a weak Type 2 response to the shared mycobacterial antigens is deliberately induced before challenge, mice are found to be strikingly more susceptible to tuberculosis than are nonimmunised control animals [30]. Similarly, in the Balb/c mouse model of pulmonary (tuberculosis) TB infection, the 
appearance of IL-4 in the lung lesions (as seen by immunohistochemistry and reverse transcriptasepolymerase chain reaction (RT-PCR) coincides temporally and spatially with the appearance of areas of pneumonia and necrosis, leading to rapid clinical deterioration and death [31]. These observations are not contradicted by the claim that, in IL-4 genedisrupted mice, there is no evidence of increased resistance to the infection [32]. First, such mice are not devoid of Type 2 cytokine activity because IL-13 can substitute for many functions of the knocked out gene. Secondly, the detrimental role of the Type 2 response is most apparent in the late progressive phase of the disease, particularly after day 60 [30, 31]. The role of Type 2 responses in immunopathology is discussed later.

Variability of tuberculosis in different mouse strains. Can we assume that the immunology of tuberculosis is similar in mouse and man? Unfortunately, the nature of the disease caused by $M$. tuberculosis depends upon the mouse strain. For instance, $\mathrm{A} / \mathrm{J}$ mice develop progressive interstitial pneumonitis, while C57BL/6 mice can develop massive granulomas [33] so the immediate cause of death can vary. Similarly, mice in which the gene for Intercellular Adhesion Molecule-1 (ICAM-1) has been disrupted, have essentially normal immunity to tuberculosis despite a lack of granulomata and a lack of delayedtype hypersensitivity (DTH) responses [34]. Therefore, it is not certain which model is most similar to human tuberculosis, and direct study of human disease is needed to determine the crucial cytokine balance required for immunity to tuberculosis in man.

\section{T cell-mediated immunity to tuberculosis in man}

Patterns of response to mycobacterial antigens. Some confirmation of the need for Type 1 responses in man, as in mice, emerged from comparisons of patients and healthy contacts. For instance, patients produce relatively more antibody, whereas normal contacts produce relatively stronger $\mathrm{T}$ cell responses to the $30 \mathrm{kDa}$ antigens of $M$. tuberculosis. Moreover, the cells from patients release less IFN $\gamma$ and more IL-10 in the presence of the antigen [35]. Similarly, $\mathrm{T}$ cells from BCG-immunised subjects respond more to the $16 \mathrm{kDa}$ alpha-crystallin protein of $M$. tuberculosis than do T cells from tuberculosis patients, who in contrast, have higher levels of antibody to it [36]. Findings of this type suggest that Type 1 responses are protective, as in mice. The study of serum concentrations of cytokines is uninformative in tuberculosis [37].

Genetics of susceptibility to tuberculosis; natural gene knockouts. Conventional genetic studies of tuberculosis patients showed that polymorphisms in genes encoding natural-resistance-associated macrophage protein (NRAMP1), the IL-1 gene cluster, the vitamin $\mathrm{D}$ receptor and mannose-binding lectin were associated with susceptibility [38]. The function of NRAMP1 remains uncertain and has been reviewed
[39]. The relevance of vitamin D receptor polymorphisms is increased when there is also vitamin D deficiency as in the Gujarati population in London [40]. However the effects on disease susceptibility are small, and so far studies of this type have cast little light on the mechanisms of immunity.

On the other hand definitive evidence that the Type 1 response is crucial for immunity to tuberculosis in man has come from the study of children with genetic defects of the Type 1 cytokine system. Vaccination with BCG, an avirulent derivative of the organism responsible for bovine tuberculosis, occasionally causes disseminated infection. The gene for the IFN $\gamma \mathrm{R} 1$ gene in such a child, had a single nucleotide deletion that resulted in the creation of a premature stop codon near the N-terminus [41]. Another study [42] involved four children from the same small town in Malta, who presented with disseminated mycobacterial infections. The mycobacterial species isolated were Mycobacterium fortuitum, Mycobacterium avium (2 strains) and Mycobacterium chelonei. One child also had prolonged salmonellosis. These children had a single nucleotide substitution (A for C) rather than a deletion [42]. It allowed normal levels of expression of the messenger ribonucleic acid (mRNA), but again introduced a premature stop codon.

IL-12 receptor deficiency has also been found in otherwise healthy individuals with mycobacterial infections. Unlike the children with IFN $\gamma$ R deficiency, these patients are able to form mature granulomata, but their natural killer (NK) cells and T cells secrete little IFN $\gamma$. Thus, IL-12-dependent IFN $\gamma$ secretion in humans, seems essential in the control of mycobacterial infections, despite the formation of mature granulomas $[43,44]$.

\section{The T cell types involved in immunity}

In addition to conventional $\mathrm{CD}^{+} \alpha / \beta$ Class II MHC-restricted $\mathrm{T}$ cells, several other $\mathrm{T}$ cell types are also involved in the response to mycobacteria.

$C D 8^{+}$T lymphocytes. Experiments, involving adoptive transfer, in vitro cell depletion, and gene knock-out (e.g. $\beta 2$-microglobulin deficient animals), have illustrated the importance of $\mathrm{CD}^{+}$cells in the control of tuberculosis in mice $[23,45,46]$. Protection of mice vaccinated with mycobacterial heat shock protein 65 deoxyribonucleic acid (DNA) appears to be mediated mainly by $\mathrm{CD}^{+}$ cells [47]. In an in vitro system, this ability to activate $\mathrm{CD}^{+}$cells seemed to involve causing leakiness of the phagosome so that antigens reach the cytoplasm and hence join the conventional pathway for presentation on MHC Class 1 [48, 49], though another novel pathway may also be involved [50]. A haemolysin-like molecule is in fact expressed by both $M$. tuberculosis and $\mathrm{BCG}$ [51], and a BCG strain expressing the haemolysin from Listeria monocytogenes has been developed in the belief that this will increase the $\mathrm{CD} 8{ }^{+}$response [52].

These $\mathrm{CD} 8^{+}$cells have been shown to be cytotoxic, though the mechanism of this cell killing has been controversial. It has been thought that most cytoxic T- 
lymphocytes (CTLs) act to lyse infected cells and allow the released mycobacteria to be taken up by activated, uninfected macrophages that may kill them. However, it now appears that some CTLs directly kill $M$. tuberculosis via a granule-associated protein, granulysin, acting with perforin [53]. On the other hand, lysis by $\mathrm{CD}^{+}{ }^{+}$cytotoxic $\mathrm{T}$ cells does not reduce the viability of the contained bacteria [54]. Progression of tuberculosis in mice deficient in perforin is not different from progression in the wild-type $[55,56]$. The major role of murine $\mathrm{CD}^{+}$cells at this stage may be the secretion of IFN $\gamma$ [57, 58]. Recently, tuberculosis-specific CD ${ }^{+}$ cells have also been identified in humans [59, 60], but their role in this species is equally uncertain. There are $\mathrm{CD}^{+}$cells that will recognise TB-infected cells and secrete IFN $\gamma$ in blood from individuals with the disease [61], but these did not appear to contribute to control of intracellular proliferation of $M$. tuberculosis in an in vitro system using human cells [62].

Most tuberculosis-specific $\mathrm{CD} 8^{+}$cells recognise their antigens in association with MHC class I, however some are now known to be restricted by other molecules, such as CD1 (see below) [63, 64].

CD1 restricted lymphocytes. The relatively nonpolymorphic CD1 family of molecules are MHC class I-like, and possess a hydrophobic cleft that binds lipid and glycolipid molecules and allows their presentation to a variety of CD1-restricted cells, including $\alpha \beta \mathrm{T}$ lymphocytes negative for both CD4 and CD8 molecules (so-called double-negative T cells), $\gamma \delta \mathrm{T}$ cells and certain $\mathrm{CD} 4^{+}, \mathrm{CD} 8^{+}, \mathrm{CD} 8 \alpha / \alpha^{+}$and NK lymphocytes $[65,66]$.

The exact roles of CD1, and CD1-restricted cells, in either the protection or pathology of tuberculosis, have proven difficult to evaluate, because mice possess a homologue of CD1d but no homologues of human CD1a, b or c. Indeed, mice deficient in CD1d have not been found to differ from controls in their susceptibility to tuberculosis [67], though there is one claim that neutralisation of CD1 resulted in exacerbation of the infection in mice at very early time points [68]. The relevance of these findings to human disease is doubtful. Human CD1d has not been shown to present mycobacterial antigens, unlike CD1a, b and $\mathrm{c}$ which may present mycolic acid, lipoarabinomannan and other mycobacterial cell wall components [69-71].

Double negative (CD4- CD8- $\alpha \beta \mathrm{T}$ cell receptor (TCR)) lymphocytes can recognise mycobacterial lipids in the context of CD1. Their predominant effector mechanisms appear to be the secretion of IFN $\gamma$ and CD95/CD95L interactions, and only rarely do they cause significant mycobacterial death [64]. This has prompted suggestions that their role is the downregulation of local inflammatory responses by the removal of antigen-loaded antigen presenting cells. Many of the other types of human CD1-restricted T cell also produce significant amounts of IFN $\gamma$, but appear able to lyse infected cells and directly kill intracellular mycobacteria [53, 64, 71].

It appears that $M$. tuberculosis may be able to downregulate $\mathrm{CD} 1$ expression on human antigen presenting cells, thereby potentially evading this component of the immune response [72].
Gamma-Delta T lymphocytes. As discussed previously some $\gamma \delta \mathrm{T}$ lymphocytes recognise lipid and glycolipid mycobacterial products in the context of CD1 molecules. However, the predominant human peripheral blood subtype, $\mathrm{V} \gamma 9 \mathrm{~V} \delta 2$, also proliferates and secretes cytokines when exposed to protein [73-75] and other nonprotein [76, 77] antigens derived from $M$. tuberculosis. $\gamma \delta$ cells are known to accumulate early in experimental lesions [78] and in vitro studies have demonstrated cytotoxicity towards infected macrophages [79]. Mouse models suggest that $\gamma \delta$ cells play a role in protection from high dose, systemic $M$. tuberculosis innocula, but are less important for protection against small, aerosol challenges [80, 81]. In the latter case, a regulatory role is suggested because mice deficient in $\gamma \delta$ cells have a higher initial bacterial burden and then develop a more pyogenic and destructive response, potentially correlating with the exaggerated pathology seen in tuberculosis patients with low levels of $M$. tuberculosis-reactive $\gamma \delta$ cells [82].

The peripheral blood $\gamma \delta$ cells of tuberculous patients appear phenotypically activated (with up-regulation of ICAM-1 and MHC class II] [83], but until recently there has been controversy as to their overall numbers in both patient blood and bronchoalveolar lavage (BAL). This has largely been resolved by the demonstration of rapid up-regulation of surface CD95-L on $\gamma \delta$ cells and prompt activation-induced cell death, making the timing of analyses vital $[84,85]$.

$T$ cell apoptosis. In short term culture, stimulation with $M$. tuberculosis antigens induces significant $\gamma \delta$ cell apoptosis in both patients and normal subjects, by a mechanism involving Fas (CD95) [84]. This may relate to the induction of Fas ligand expression upon engagement of the $\gamma \delta \mathrm{T}$ cell receptor by mycobacterial antigens [85]. The effect on $\mathrm{CD}^{+} \mathrm{T}$ cell apoptosis may depend on the mycobacterial preparation and duration of culture. One group, using cells from tuberculosis patients, has noted a 2fold increase in CD4 $\mathrm{T}$ cell apoptosis induced by live $\mathrm{H} 37 \mathrm{Ra}$ at $96 \mathrm{~h}$. The effect is no longer seen in the same patients post-treatment [86]. There is also a report that tuberculosis infection causes increased Fas expression and decreased bcl-2 expression in $\mathrm{CD}^{+}{ }^{+}$ $\mathrm{T}$ cells. When such $\mathrm{T}$ cells are stimulated in vitro, they show increased apoptosis and decreased production of IL-2 and IFN $\gamma$ but not of IL-4. This suggests selective apoptosis of Th1-like cells, which may be a factor in the switch towards Th2 [87, 88].

\section{Type 2 responses in human tuberculosis}

These observations, and above all, the susceptibility of children with defective receptors for IFN $\gamma$ or IL-12, provide definitive evidence of the importance of Type 1 cytokines, and suggest a close parallel with the mouse models. Recently, the negative role of Type 2 cytokines in human tuberculosis (TB), again paralleling the murine models, has been established [89, 90]. Expression of IL-4, whether measured by flow cytometry, or by sensitive quantitative RT-PCR on unstimulated pe- 
ripheral blood T cells [91], is increased (fig. 1) and correlates with severity of disease and with cavitation $[89$, 90]. The IL-4 mRNA copy number also correlates with total immunoglobulin-E (IgE) (fig. 1) [89] and with levels of soluble CD30 (unpublished data). Thus although it is true that actual cytokine levels and mRNA copy numbers are higher for Th1 than for Th2 cytokines in tuberculosis, the major change in cytokine expression compared to healthy donors is not as previously stated, the small decrease in expression of Th1 cytokines, but rather a massive $(80-100$-fold) increase in expression of Th2 cytokines [89]. This has resolved a long-running controversy which deserves explanation. That there is a Th2 component in the response of human tuberculosis patients to $M$. tuberculosis ought to have been accepted 10 years ago, because there is no other known explanation for the presence of specific $\operatorname{IgE}$ antibody [92]. Interestingly, the other largely Type 2 cytokinedependent antibody, immunoglobulin-G4 (IgG4) is also reported to be increased in patients [93]. Similarly, immunohistochemistry reveals IL-4-expressing cells in the lymphoid tissue of tuberculosis patients (but not in tissue from patients with sarcoidosis) [94].

Why then, has the matter been controversial $[95,96]$ ? First, IL-4 is biologically active at much lower concentrations than IFN $\gamma$, and has a correspondingly lower mRNA copy number, so methods that reliably pick up IFN $\gamma$ or its mRNA fail to detect biologically significant levels of IL-4. Secondly, attempts to increase cytokine expression by stimulation of the cells in vitro do not yield an accurate reflection of the cytokine balance present in vivo, and rapid early production of IFN $\gamma$ can suppress Th2 cytokine release. Finally, previous studies failed to take into account the presence of the IL-4 splice-variant (IL-482). This variant of IL-4 may be an inhibitor of IL-4 activity, and is always coexpressed with IL-4, at about the same level [97]. In lung cells it may be expressed at higher levels than IL-4 itself. However, almost every study of IL-4 mRNA levels used primers that would amplify mRNA for both IL-4 and the splice variant.

The mechanisms of the shift towards a Type 2 cytokine profile. It is possible that some of the relative deficit in IFN $\gamma$ expression [89] and lymphoproliferation in the peripheral blood of tuberculosis patients is due to sequestration of the antigen-recognising cells in the lymph-nodes [98] or site of disease [99]. However this cannot fully explain the massive rise in expression of Type 2 cytokines [89]. What then, are the likely causes of this shift in cytokine profile? Several possibilities are shown in figure 2. Increasing antigen load is likely to be one factor, since the Th1/Th2 balance is strikingly linked to dose when immunising with particulate antigens such as mycobacteria [100] or leishmania [101]. In some populations, excessive or inappropriate contact with environmental mycobacteria may have primed a Type 2 response to the crucial common antigens. This mechanism is clearly demonstrable in mice, in which it can massively increase susceptibility, and has been suggested, but not conclusively proven, in man [102, 103].

During active infection, selective apoptosis of Th1like $\mathrm{T}$ cells may be a factor [87, 88], as may prostaglandin release $[104,105]$ and increased secretion of transforming growth factor- $\beta$ (TGF $\beta$ ) and IL-10 [106]. However, the latter may be a consequence of the shift towards a Type 2 profile rather than its cause.

Finally there are now strong reasons for suggesting that endocrine interactions with the immune system are important. Vitamin $\mathrm{D}_{3}$, cortisol metabolism and dehydroepiandrosterone levels are discussed later in the endocrinology section.
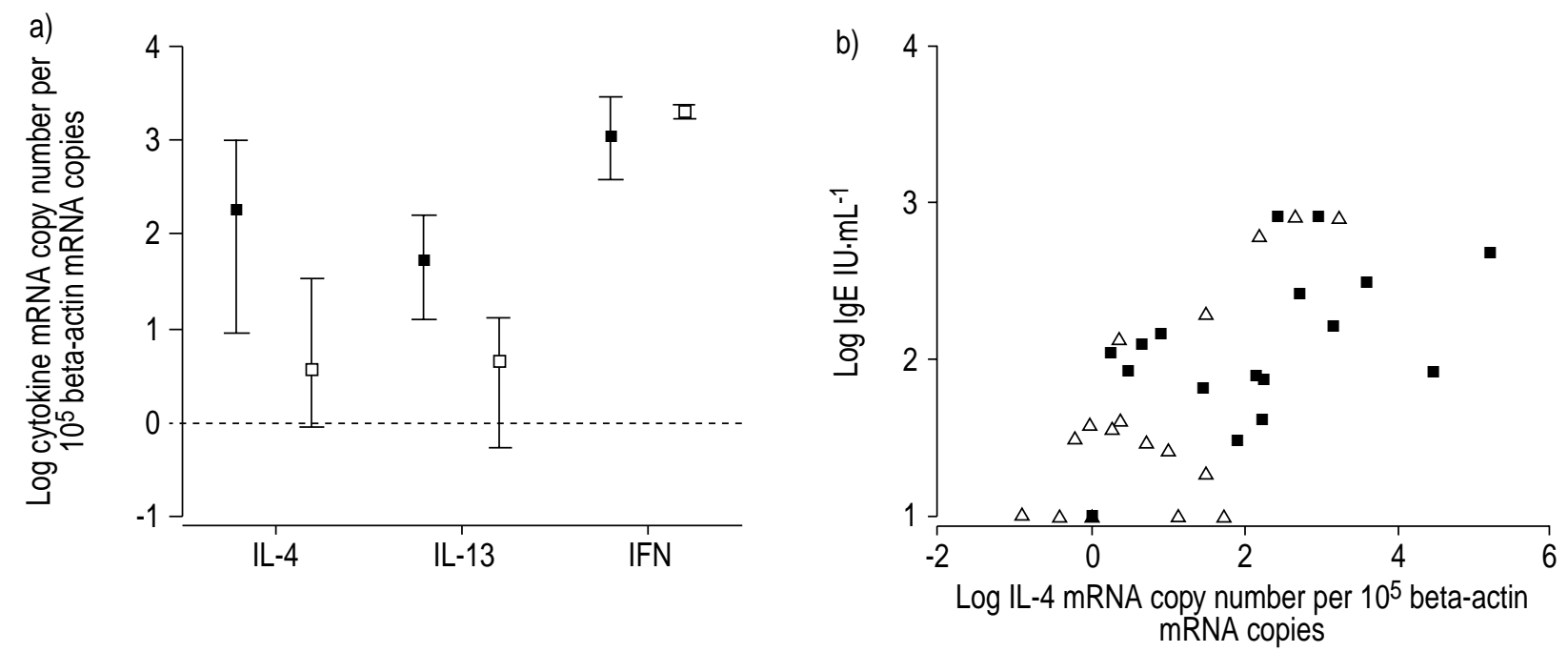

Fig. 1. - a) Quantitative reverse transcriptase polymerase chain reaction using fresh unstimulated peripheral blood monuclear cells from tuberculosis patients ( $\square$ ) and from tuberculin-positive healthy donors ( $\square$ ) matched for age, race and sex, reveal that although the messenger ribonucleic acid (mRNA) copy number for Type 1 cytokines remains higher than that for Type 2 cytokines, the major change in tuberculosis is an increase in Type 2 cytokine expression (interleukin- 4 (IL-4), $p=0.004$ and interleukin-13 (IL-13), $p=0.0009$ respectively by Mann-Whitney test). Medians are shown; 25th and 75th percentiles marked as error bars. b): IL-4 mRNA copy number correlates with the serum immunoglobulin-E (IgE) levels implying that this mRNA is translated into active cytokine. $\boldsymbol{\square}$ : tuberculosis patients; $\triangle$ : healthy controls. Adapted from [89]. 


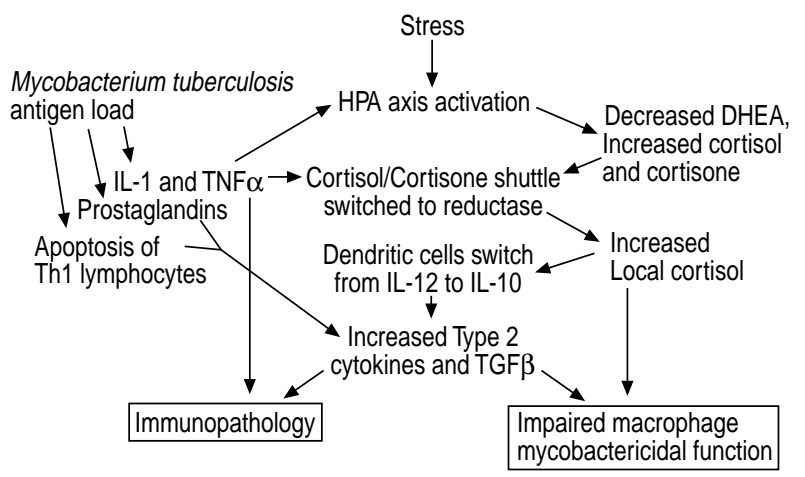

Fig. 2. - Possible model of the mechanisms that may lead to excessive activation of Type 2 cytokines in human tuberculosis. These can impair mycobactericidal functions of macrophages, and in concert with tumour necrosis factor $\alpha$ (TNF $\alpha)$, contribute to immunopathology. IL: interleukin; HPA: hypothalamicpituitary axis; TGF $\beta$ : transforming growth factor $\beta$; DHEA: dehydroepiandrosterone.

\section{The protective role of tumour necrosis factor (TNF)}

This proinflammatory cytokine can have either protective or detrimental effects in murine disease, and the same is likely to be true in man, as discussed later in relation to immunopathology. Its effects appear to depend upon the other cytokines present. In the mouse, tumour necrosis factor (TNF) is protective early in infection. TNF levels are elevated early (day 3) in mice infected via the intratracheal route, and reach a second peak in the third week, coinciding with mature granuloma formation [107]. TNF receptor knockout mice succumb faster to $M$. tuberculosis infection than control mice [108], and a disruption of the granulomatous response and increase in mycobacterial load is noted in $M$. tuberculosis-infected mice when TNF bioactivity is blocked [109].

\section{Macrophage function and M. tuberculosis}

Uptake of mycobacteria. Mycobacteria are taken up by multiple pathways including complement receptors and mannose receptors $[110,111]$. However, this is clearly not the whole story, because in vitro, $M$. tuberculosis can enter a variety of cell types that do not express these receptors $[112,113]$. The exact mode of uptake must affect the subsequent fate within the cell [114].

Toll-like receptors. Much of the initial activation and cytokine response of macrophages to mycobacteria may be mediated by interaction with the Toll-like receptors (TLRs). These are members of the IL-1 receptor family, related to Toll, a molecule involved in innate microbial resistance mechanisms in Drosophila. Endotoxin activates cells by interacting with CD14 and TLRs, and some mycobacterial lipoarabinomannan (LAM) preparations may work similarly, though possibly involving a different TLR [115]. However both virulent and attenuated strains of $M$. tuberculosis can activate in a TLR-dependent manner that has no requirement for membranebound or soluble CD14. TLR2, but not TLR4, could confer responsiveness to LAM isolated from rapidly growing mycobacteria. In contrast, LAM isolated from $M$. tuberculosis or Bacillus Calmette-Guérin failed to induce TLR-dependent activation. Therefore, there must be other components that interact with TLR and both soluble and cell wall-associated mycobacterial factors are involved. A soluble heatstable and protease-resistant factor was found to mediate TLR2-dependent activation, whereas a heatsensitive cell-associated mycobacterial factor mediated TLR4-dependent activation [116]. Lipoproteins can activate via TLR, and several from $M$. tuberculosis will drive IL-12 production in this way [117], perhaps explaining the latter result.

Mycobactericidal mechanisms within macrophages. Inhibition or killing of $M$. tuberculosis is easily induced in murine macrophages by exposure to IFN $\gamma$, but such effects are extremely difficult to demonstrate convincingly in human cells $[118,119]$. Success has been reported using human alveolar lavage macrophages exposed to $\mathrm{TNF} \alpha$ in vitro [120]. It is possible, though by no means certain, that the major killing mechanism is not a direct effect of activated macrophages, but rather an event that occurs during certain types of apoptosis or during killing of the macrophage by cytotoxic $\mathrm{T}$ cells that "inject" granulysin and perforin (see section on $\mathrm{CD}^{+}$effector cells previously) (fig. 3).

Reactive oxygen and nitrogen intermediates. If macrophages do themselves kill $M$. tuberculosis these are likely candidate killing mechanisms (fig. 3). Inhibitors of the production of nitrous oxide (NO) aggravate tuberculosis infection as assessed by mortality, bacterial burden, and histopathology [121, 122]. The mechanism of action of the NO is uncertain, because it has important signalling and second messenger functions that may be as important as direct toxicity for the organisms [123]. Moreover, KO mice unable

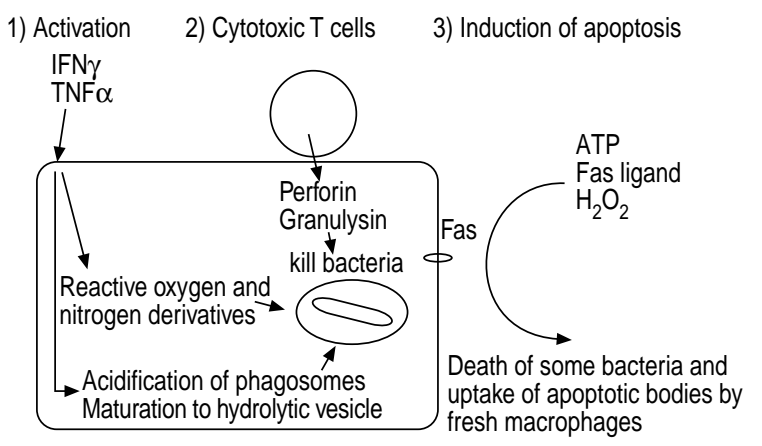

Fig. 3. - Multiple macrophage mechanisms attempt to kill Mycobacterium tuberculosis. It is still not clear which are the important mechanisms leading to killing of M. tuberculosis, particularly in human cells where killing is very difficult to achieve in vitro. Candidate pathways are shown, and all are referenced and discussed in the text. Note that only some inducers of apoptosis result in reduced viability of the contained bacteria. Further activation must occur via the Toll-like receptors but their role in killing is not yet known. IFN $\gamma$ : Interferon- $\gamma$; TNF $\alpha$ : tumour necrosis factor $\alpha$; ATP: adenosine triphosphate; $\mathrm{H}_{2} \mathrm{O}_{2}$ : hydrogen peroxide. 
to make NO or other reactive nitrogen intermediates (RNI) showed no increase in proliferation of $M$. tuberculosis in the lungs until very late in the infection, but there was increased growth in the spleen. In contrast, KO mice, unable to make reactive oxygen intermediates (ROI), had increased growth of bacilli in the lungs. Interestingly, activation of macrophages by IFN $\gamma$ in vitro to control proliferation of $M$. tuberculosis was dependent upon RNI rather than ROI, and so appeared to parallel immunity in the spleen rather than in the lungs [124]. However the situation remains complex, and in a model of $M$. avium infection, knocking out the inducible nitric oxide synthase (iNOS) gene actually improved clearance of bacteria from the spleen. This may be due to the fact that in the murine spleen, NO levels can reach immunosuppressive levels [125]. The role of NO in man remains unclear. It is probably made by appropriately activated human macrophages [126], but never in the very large quantities that murine macrophages can release. Thus the levels released by human cells may stay in the beneficial antimicrobial range $[127,128]$, though there is not universal agreement about the anitmycobacterial relevance of this mechanism [129]. There is some evidence that $1,25(\mathrm{OH})_{2} \mathrm{D} 3$ may be involved in the activation of iNOS in a human monocyte cell line [130], so this could explain the animycobacterial effect of this material [118]

Macrophage apoptosis. Involved lobes in human tuberculous lung sections have been found to contain more apoptotic macrophages than noninvolved lobes [131]. However, most work on apoptosis in tuberculosis has been based on responses in cell culture models of mycobacterial infection. Infection with virulent $M$. tuberculosis decreases viability of healthy human alveolar macrophages (when compared to heat-killed mycobacteria), and inhibiting TNF $\alpha$ may partially reverse this $[132,133]$. Cells containing $M$. tuberculosis are markedly more sensitive to killing by $\mathrm{TNF} \alpha[113]$.

Death of the infected macrophage can be associated with death of the contained mycobacteria (fig. 3). Nevertheless, it has been suggested that reduction in bacillary numbers is only achieved by apoptosis of infected monocytes, not by the necrotic mode of death $[134,135]$. Apoptosis induced by adenosine triphosphate (ATP) promotes killing of virulent $M$. tuberculosis within human macrophages $[136,137]$ as does apoptosis induced by Fas Ligand [134], and hydrogen peroxideinduced apoptosis also causes mycobactericidal effects [138]. Addition of fresh uninfected autologous macrophages to cultures of apoptotic $M$. avium-infected macrophages results in $90 \%$ inhibition of bacterial growth. Apoptosis also prevents the release of intracellular components and the spread of mycobacterial infection by sequestering the pathogens within apoptotic bodies [139].

Evasion of the antimicrobial functions of macrophages. Mycobacteria have various strategies for avoiding being killed by phagocytes (fig. 4) [140]. M. tuberculosis may be taken up via mannose receptors that fail to trigger killing events. It also inhibits complement-receptor-mediated $\mathrm{Ca}^{2+}$ signalling, which may contribute to the failure of killing mechanisms [141]. Mycobacteria can inhibit acidification of the phagosome [142] and modify intracellular trafficking of vacuoles, so they behave like part of the endosomal recycling compartment, rather than as toxic phagolysosomes [143]. These vacuoles release quantities of LAM which insert into glycosylphosphatidylinositol (GPI)-rich domains in the cell membrane [144]. LAM is itself a GPI of unusual glycan structure, with the ability to modify numerous macrophage functions including the ability to respond to IFN $\gamma$, and the ability to present antigen (reviewed in [144]). The last point may be relevant to the apparent inability of long-term mycobacteriuminfected macrophages to present antigen to $\mathrm{CD}^{+}$ $\mathrm{T}$ cells [145]. One mechanism used by LAM may be the activation of protein tyrosine phosphatase SHP-1, a phosphotyrosine phosphatase, intimately involved in cell signalling pathways [146].

The pattern of cytokine release from infected macrophages changes so that macrophage activation is diminished, and T cell recruitment impaired (fig. 4). Recruitment of Th1 lymphocytes requires IL-12 production, which is inhibited by increased production of TGF $\beta$ and IL-10 [106, 147, 148], and IL-6 release may also be a factor. TGF $\beta$ and IL-10 also impair macrophage microbicidal function and the IL-10

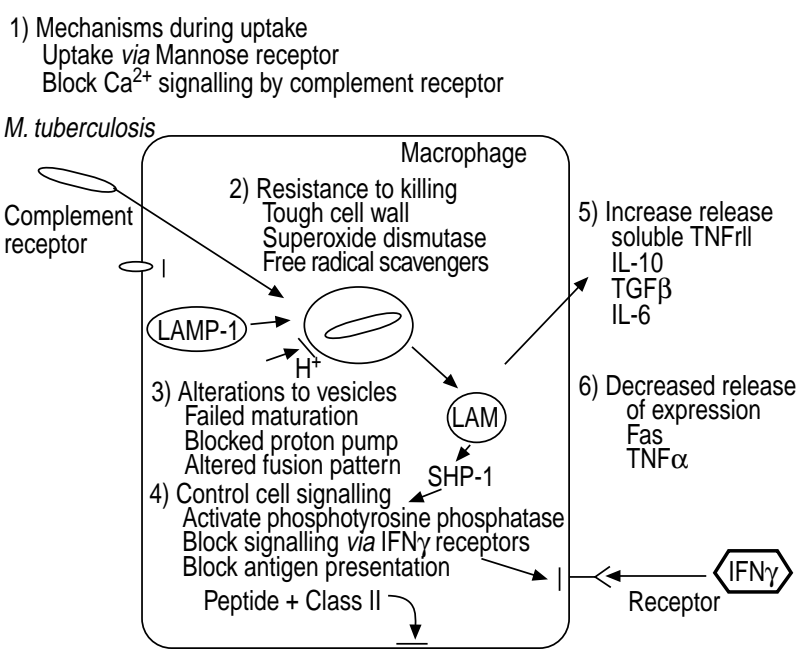

Fig. 4. - Mycobacterium tuberculosis avoids being killed by macrophages. This figure should be compared with figure 3 . Each of the killing pathways in figure 3 is opposed by some mechanisms in figure 4. Short thick lines indicate blocked pathways. Most of the figure is self-explanatory. Uptake via mannose receptors may avoid triggering killing mechanisms. The vacuoles containing mycobacteria lie within the sorting/recycling endosomal machinery of the macrophage, and fail to acidify and fuse with acidic lysosomes. But they do fuse with lysosome activated protein (LAMP-1)-containing endosomes and they release lipoarabinomannan (LAM)-containing vesicles. Thus their fusion pattern is altered by the pathogen. SHP-1: is a phosphotyrosine phosphatase. TNFrII: tumour necrosis factor rII; IL: interleukin; TGF $\beta$ : transforming growth factor $\beta$; TNF $\alpha$ : tumour necrosis factor $\alpha$; IFN $\gamma$ : interferon $\gamma$. 
contributes to increased release of TNF receptor-2, which blocks the activating role of TNF $\alpha$ [149].

As described earlier, certain types of apoptosis appear to reduce the viability of the contained mycobacteria. It has been noted that the release of soluble Type 2 TNF receptors (sTNFRII) induced by virulent strains of $M$. tuberculosis may limit the apoptotic death of infected alveolar macrophages and they also have reduced Fas expression which may limit this pathway of apoptosis induction too [134]. This has led some investigators to hypothesize that pathogenic mycobacteria may actually be modulating the host immune response to minimise macrophage apoptosis (fig. 4). A point against this hypothesis, is that infected macrophages may also have down-regulated mRNA expression of bcl-2, an inhibitor of apoptosis [131]. It may be that the organism is preferentially inducing forms of apoptosis that leave the organisms unharmed.

\section{Immunopathology}

\section{The toxicity of $\mathrm{M}$. tuberculosis}

Live $M$. tuberculosis is inherently toxic to cells. For instance, human or murine macrophages that ingest more than about 5 organisms usually die, whereas $M$. avium strains or Mycobacterium leprae can multiply to remarkable numbers within cells without killing them. It has been suggested that $M$. tuberculosis may produce a lipid toxin similar to that produced by Mycobacterium ulcerans (the cause of Buruli ulcer) [150]. It is also clear that $M$. tuberculosis releases a factor that greatly increases the sensitivity of infected cells to the toxicity of TNF $\alpha$ which is likely to be present in all tuberculous lesions [113, 151].

Although $M$. tuberculosis clearly has some inherent toxicity, this does not fully explain the pathology of the disease. Tuberculin or purified protein derivative (PPD) are remarkably nontoxic both in vivo and in vitro, but in suitably prepared humans or animals they will provoke necrosis, which is clearly due to immunopathology.

The Koch phenomenon; the response characteristic of disease

As outlined earlier, КocH [14] noted that 4-6 weeks after establishment of infection in guinea-pigs, intradermal challenge with whole organisms or culture filtrate resulted in necrosis locally, and in the original tuberculous lesion. Similar phenomena occur in humans. The tuberculin test is frequently necrotic in subjects who are, or have been, tuberculous. This is not an inevitable consequence of the delayed hypersensitivity response to tuberculin because necrosis does not occur when positive skin-tests to tuberculin are elicited in normal BCG recipients, or in tuberculoid leprosy patients. Moreover, Koch sought to exploit this phenomenon for the treatment of tuberculosis, and found that injection of larger quantities of culture filtrate (Old Tuberculin), subcutaneously into tuberculosis patients, would evoke necrosis in established tuberculous lesions at distant sites [152]. This resulted in necrosis, sloughing and "cure" of the lesions of skin tuberculosis (Lupus vulgaris, usually caused by bovine strains), but when similar necrosis was evoked in deep lesions in the spine or lungs, the results were disastrous, and merely provided further necrotic tissue in which the bacteria could proliferate. This treatment was therefore abandoned.

The error in Koch's thinking was highlighted in the 1940s. When guinea-pigs were preimmunised so that they had powerful Koch phenomena in response to small doses of tuberculin, they became more susceptible to tuberculosis than nonimmunised control animals [15]. Obviously this was seen only if the challenge infection was into the lungs, or by deep intramuscular injection, so that necrosis could not result in shedding of the infected tissue.

The relationship between the Koch phenomenon and the Shwartzman reaction

Koch's discovery that soluble bacterial material could trigger necrosis in a distant tuberculous site has some parallels with the SHWARTZMAN [153] reaction and subsequent experiments strengthen the parallel still further. For instance, injections of endotoxin-rich material into a distant site (instead of the tuberculin used by Koch) will also trigger necrosis in tuberculous lesions [154-156], and injections into the flank of another cytokine trigger, muramyl dipeptide (MDP), caused necrosis in sites of inflammation due to complete Freund's adjuvant [157]. These observations are compatible with the view that tuberculous lesions are susceptible to superimposed cytokine-mediated damage.

\section{The cytokine-sensitivity of mycobacterial lesions in mice}

There is also the possibility that there is failure of an important regulatory role of $\gamma / \delta \mathrm{T}$ cells, that may lead to greater tissue destruction [82]. However, a better characterised explanation for these findings is the increased susceptibility to cytokine-mediated tissue necrosis of tissues undergoing inflammation mediated simultaneously by Type 1 and Type 2 cytokines. This is easily demonstrated in Balb/c mice with pulmonary tuberculosis [158]. During the first 3 weeks, DTH sites were not sensitive to local injection of as much as $1 \mu \mathrm{g}$ of recombinant TNF $\alpha$. This is the period of Type 1 response [159]. After 50 days, the animals enter a phase of slowly progressive disease accompanied by increasing Th2 cytokine production seen as IL-4 positive cells in the lesions. In these animals, DTH sites become $\mathrm{TNF} \alpha$-sensitive $[30,100]$. This propensity for TNF toxicity in the presence of interleukin-4 is supported by several examples in nonmycobacterial models. LAWRENCE and coworkers [160], studying Trichinella spiralis infection in mice, have found that the enteropathy caused by TNF is dependent upon IL-4. Other murine studies have also revealed that $\mathrm{Th} 2$ cells may mediate local tissue inflammation which is IL-4 dependent [161] and in certain murine strains, DTH caused by Th 2 cells correlates with TNF production by 
the cells [162]. If an important component of the Koch phenomenon is cytokine-mediated damage in a site of mixed Type 1/Type 2 inflammation, then the toxicity of Koch's "treatment" for tuberculosis is easily explained (fig. 2) [152].

\section{Detrimental roles of tumour necrosis factor-alpha in human tuberculosis}

The previous section suggested that a component of the immunopathological state in human tuberculosis may result from the simultaneous presence of Type 1 and Type 2 cytokines, and TNF $\alpha$. An increase in plasma $\mathrm{TNF} \alpha$ levels has been associated with clinical deterioration in patients with severe tuberculosis [163]. Both thalidomide and pentoxifylline, as inhibitors of $\mathrm{TNF} \alpha$ release, have been tried as treatments for the cachexia of chronic disease [164]. In vitro studies suggest that pentoxifylline enhances macrophage survival when used to treat $M$. tuberculosis-infected macrophages [133] but it failed to reverse cachexia in human studies [164]. However thalidomide, which reduces IL-6, IL-10 as well as TNF levels, and reduced lung pathology in a murine model [165], was clearly clinically beneficial in the human disease [166].

\section{Endocrinology}

There are several endocrine and metabolic changes in tuberculosis that may contribute to the failure of the Type 1 response to control the infection, and to the increasing level of Type 2 cytokine expression.

\section{Vitamin $D_{3}$ metabolism in tuberculosis lesions}

The macrophages of tuberculosis patients, following activation by IFN $\gamma$, express an active $1 \alpha$-hydroxylase, and rapidly convert $25(\mathrm{OH})$-vitamin- $\mathrm{D}_{3}$ to calcitriol $[118,167]$. This is a potent phenomenon, leading occasionally to leakage of calcitriol into the periphery, and to hypercalcaemia, though it has in the past been difficult to understand its role in the disease [167]. It now seems possible that this is a feedback mechanism that tends to down-regulate Th1 and enhance Th2 responses, because calcitriol inhibits production of IFN $\gamma$ and IL-2, and increases production of IL-4 and IL-5 [168, 169]. This may well be related to the ability of calcitriol to inhibit release of IL-12 [170]. The true physiological relevance of these effects in vivo remains unproven, but the synthesis of novel analogues of calcitriol with less tendency to cause hypercalcaemia has allowed them to be tested as suppressors of Th1 responses in in vivo models. Some of these analogues will prolong allograft survival, and reduce the requirement for cyclosporin A [171].

In the 1940 's attempts were made to treat tuberculosis with vitamin D. When patients with skin tuberculosis (Lupus vulgaris, often due to Mycobacterium bovis) were treated with this vitamin, the chronic nonhealing granulomatous lesions often underwent necrosis followed by resolution [172]. However, necro- sis and liquefaction also occured in deep lesions in the spine and lungs [173], so the result was as disastrous as the use of Koch's immunotherapy described previously [152]. The mechanism of this effect remains unknown, but an increase in Type 2 cytokine expression in granulomata rich in Type 1 cytokines and TNF $\alpha$ would be expected to cause necrotising immunopathology as discussed earlier.

\section{Adrenal steroids in tuberculosis}

The effects of stress. Glucocorticoids cause a switch to Type 2 cytokine production [174, 175], probably because of effects on dendritic cells, which secrete less IL-12 and more IL-10 in their presence [176, 177], but glucocorticoids also directly synergise with some effects of Type 2 cytokines [178] and down-regulate the antimycobacterial effects of macrophages [179, 180]. It is therefore not surprising that reactivation or progression of infection with tuberculosis is sensitive to glucocorticoid therapy and to activation of the hypothalamopituitary adrenal axis. Exposing humans to the stress of war or poverty [3] or cattle to the stress of transportation are enough to cause reactivation of disease. The disease-promoting effect of stress has been demonstrated under more controlled conditions in mice $[181,182]$.

Activation of the hypothalamo-pituitary-adrenal (HPA) axis during the infection in mice. In mice infected with virulent $M$. tuberculosis by the tracheal route, there is early activation of the HPA axis, which correlates with the initiation of the switch from "pure" Type 1 to mixed Type 1/Type 2 infiltration of the lungs [183]. Although this association is circumstantial, it may be significant that treatment with the antiglucocorticoid steroid dehydroepiandrosterone (DHEA) or the closely related androstenediol, can delay, or even reverse this switch towards a Type 2 cytokine profile, while corticosterone supplements at a physiological level enhance the cytokine changes [183, 184].

The HPA axis in human tuberculosis. There has been much speculation about changes in the function of the HPA axis in human tuberculosis, including claims for an almost total loss of the evening glucocorticoid trough [185] and minor degrees of adrenal insufficiency revealed by challenge with adrenocorticotropic hormone (ACTH) [186]. Recent studies indicate that many previously reported findings are artefacts that disappear if the patient is allowed to acclimatise to the stressful hospital environment for several days before the tests are performed. Under these circumstances the diurnal rhythm is normal and so are the responses of the adrenals to corticotropic releasing hormone $(\mathrm{CRH})$ and to very low doses (i.e. physiological) of ACTH [187]. The total 24-h cortisol output may be normal or modestly raised. In patients with more severe disease, the 24-h output of metabolites of DHEA may be reduced, and in view of the antiglucocorticoid, and Th1-promoting effects of this steroid mentioned above, this may contribute to immunological dysfunction [188]. However, the 
most striking and consistent abnormality is a change in the pattern of metabolism of cortisol, indicating a large alteration in the equilibrium point of the cortisolcortisone shuttle, as discussed below [188].

Dysregulation of the cortisol-cortisone shuttle. A major mechanism for the regulation of local tissue cortisol levels is the interconversion of active cortisol (11hydroxy) and inactive cortisone (11-keto). Thus effective cortisol concentrations in different organs can be very different from the values found in the serum. Moreover, these enzymes are regulated. As an example, granulosa cells express 11ßHSD-1 at some stages of the ovulatory cycle (luteinising) and so at that time may be sensitive both to cortisone (after conversion to cortisol by 11ßHSD-1) and to cortisol, whereas at other times in the cycle (nonluteinised) the cells express only $11 \beta$ HSD-2 which converts cortisol to inactive cortisone, and so will not be sensitive to either steroid [189]. Gas chromatography and mass spectrometry revealed a striking excess of metabolites of cortisol, relative to metabolites of cortisone in 24-h urine collections from tuberculosis patients [188]. This imbalance returned to normal during treatment. The findings were further supported by the observation that tuberculosis patients more rapidly converted an oral load of cortisone into cortisol (measured in plasma) than did control individuals or cured tuberculosis patients [190].

Subsequent studies in tuberculous mice and analysis of alveolar lavage samples from tuberculosis patients and controls, have revealed that the site of abnormal conversion of inactive cortisone to active cortisol in the patients, is the infected lung itself $[187,190]$. This may be explained by the observation that TNF $\alpha$ and IL-1 $\beta$ both increased the expression levels and reductase activity of $11 \beta-H S D-1$ in a cell line in vitro [191]. However, the relative increase in reductase activity could also be due to a decrease in the activity of $11 \beta$ HSD-2, since it has recently become apparent that this enzyme is present in lung [192]. Further enzymological and quantitative RT-PCR studies are required. Whatever enzymes are involved, the result is a local increase in cortisol levels that is not apparent from measurements of serum cortisol. This cortisol excess will cause a shift towards Type 2 cytokine expression, deactivation of the antimycobacterial effects of macrophages, increased IL-10 and increased TGF $\beta$, so it can account for many of the changes seen in the human disease.

\section{Vaccination}

BCG vaccination is remarkably safe [193]. However, the protective efficacy varies from $80 \%$ protection to no protection at all in different populations (reviewed in [194]). BCG is most protective against tuberculous meningitis, and in some environments, progressive primary disease, but it is less effective against reactivation or reinfection. This variability does not appear to be due to the use of different batches of BCG, or to genetic differences between populations. Since BCG is the "gold standard" in animal work and is almost always better than experimental vaccines in animal models, despite its inadequacy in man, the need to understand this variability before undertaking long and expensive trials of novel vaccines in man is obvious. Three hypotheses are currently under investigation.

\section{Interference by environmental mycobacteria}

The role of ubiquitous environmental saprophytes has been explored for many years [102]. An apparent reduction in the efficacy of $\mathrm{BCG}$ could occur either because the environmental saprophytes were themselves protecting, or because they were priming deleterious patterns of response (e.g. Type 2) and so blocking the efficacy of the BCG. These two effects were suggested to be occuring in different countries [102], and both effects are easily demonstrated experimentally [30]. The crucial role of the common antigens shared between saprophytes and $M$. tuberculosis is central to these hypotheses, and is explained fully later. These mechanisms have been subjected to review and to mathematical modeling [103].

\section{Concurrent parasite infections}

Some authors suggest that the presence of concomitant parasite infections may cause a systemic bias towards Th2 responses that undermines the ability of $\mathrm{BCG}$ to induce a Th1 response to mycobacterial antigens.

\section{Vaccine dose}

Another suggestion is that BCG would be more reliable if used at a very low dose, because the dose at which the vaccine starts to evoke a deleterious Type 2 component may be much lower in some individuals than in others. This idea is derived from vaccination studies with Leishmania in different mouse strains, where a dose that evokes a Type 1 response in some strains is too high, and so Type 2-inducing, in others [101]. If there are people for whom the standard BCG dose is too high, the problem would theoretically be avoided by using very low doses. Because BCG is a live vaccine, it should still be effective. In each individual it should proliferate to the level at which a mycobactericidal Th1 response was induced [195]. In deer, $5 \times 10^{4}$ or $5 \times 10^{7}$ is protective but $5 \times 10^{8}$ is less effective, so there is clearly some truth in this idea [196]. A study in man used only in vitro parameters (IFN $\gamma$ release and lymphocyte proliferation) to compare low $\left(1.6 \times 10^{5}\right.$ colony forming units (cfu) and $\left.3.2 \times 10^{6} \mathrm{cfu}\right)$, standard $\left(1.6 \times 10^{8} \mathrm{cfu}\right)$, or high $\left(3.2 \times 10^{8} \mathrm{cfu}\right)$ doses, and concluded that the doses of more than $10^{8}$ were necessary [197]. However, without protection studies, these data cannot be interpreted. The relationship between these parameters and protection remains obscure. In one recent study, BCG vaccination of PPD skin-test negative subjects caused conversion to skin-test positivity, but had no effect on in vitro lymphoproliferation or cytokine production [198], 
and the relationship between skin-test response and protection is equally obscure.

\section{Deoxyribonucleic acid vaccines}

There has been much recent interest in DNA vaccines. This method of vaccination often induces antigen-specific $\mathrm{T}$ lymphocytes that secrete IFN $\gamma$ and show cytotoxic potential, factors that are desirable in the case of tuberculosis. This may be related to the adjuvant properties of their nonmethylated $\mathrm{CpG}$ sequences [199]. Many antigens have been studied in animal models, particularly the secreted proteins [200] and heat shock proteins [47], but, as discussed later, the relevance of such animal models to human patients is difficult to determine.

\section{Attempts to identify protective antigens using animal studies}

Enormous effort has gone into the search for "protective" antigens, in the belief that particular subsets of antigens or epitopes will prove to be optimal targets for protective immune responses. Almost all such studies have involved testing purified or recombinant antigens in mouse models of tuberculosis, in a variety of adjuvants, or expressed in Vaccinia or Salmonella [201]. Others have modified BCG in the hope of increasing its immunogenicity and its ability to induce a $\mathrm{CD}^{+}$cells response [52]. It has become clear that the usefulness of this approach is limited. Essentially all the protein antigens of $M$. tuberculosis tested in murine models will protect if they are administered in a way that induces a polarised Th1 response. Similarly, all TB antigens tried, appear to work as DNA vaccines against tuberculosis in mice [202], and the complex experimental systems do not allow slight variations in efficacy, seen to be attributed to inherent differences in their "protective" role. Some antigens only work if the optimal adjuvant is chosen after a process of trial and error. ESAT- 6 is an example which illustrates the dilemmas posed by these experiments. It is a dominant $\mathrm{T}$ cell target in early tuberculosis in man and animals [203]. But does early $\mathrm{T}$ cell recognition of ESAT-6 indicate that it is a protective antigen, or that it is a sign of a failed response and of developing disease? Mouse experiments certainly do not help. ESAT-6 will protect mice if used with a suitable complex of adjuvants, but protection is less easy to achieve than with other antigens such as hsp65 or the 30kDa group of mycolyl transferases [204].

How, therefore, should one choose antigens for vaccine trials in man, and what adjuvant should be used? Human studies are so difficult that only a subset of antigens with a high probability of success can be subjected to clinical trials. One suggestion is another round of testing in guinea-pig models. However, there is no reason to suppose that this would do more than defer the decision-making day.
Identification of protective antigens through human studies

Study of responses in contacts who do not develop disease. Clones from naturally PPD-converted individuals showed a spectrum of reactivity, some specific to $\mathrm{TB}$, others recognising all mycobacterial species tested [205]. Therefore, in order to discover whether some antigens have a specifically protective role, it is necessary to follow up individuals recently exposed to tuberculosis, so that any differences between those who do and do not develop active disease can be identified. Such studies are in progress in 3 geographically diverse African states, through a project funded by the European Community.

Common mycobacterial antigens versus species-specific epitopes. It has been known for many years that BCG is as effective a vaccine against leprosy as it is against tuberculosis, although $M$. leprae is an entirely different species [206]. BCG must therefore be able to work through common epitopes. Similarly there is evidence that contact with an environmental organism, leading to mycobacterial skin-test positivity, is protecting the population of Malawi from both tuberculosis and leprosy [207]. In mice, powerful protective or "anti-protective" effects can be induced with an environmental mycobacterial saprophyte, simply by altering the immunisation protocol so as to induce a Type 1 or Type 2 response [30]. These effects are obviously due to the common antigens. It is also significant that tuberculosis patients who still maintain necrotising skin-test positivity to antigens of M. tuberculosis itself, have diminished or absent skintest responses to environmental saprophytes [208], whereas these do evoke responses in protected populations. This is a remarkable paradox, implying that a lack of response to the common antigens may correlate with susceptibility to disease. In spite of these facts, there is a deep prejudice against the view that protection can be mediated via epitopes that are not species-specific. This prejudice dates from the era of the early antibody-mediated vaccines, since antibodies neutralise microbial components by binding conformational epitopes on toxins, enzymes or adhesion molecules. These substances are often species-restricted. The fact that $\mathrm{T}$ cells do not neutralise anything, but recognise short peptide sequences cleaved from microbial proteins, together with the fact that $\mathrm{T}$ cells are not taxonomists, should be sufficient to dispell the prejudice. The concept of species-specificity is irrelevant to $\mathrm{T}$ cell function. It is also important to remember that the clonal selection theory as originally formulated by BURNET [109] is now an outdated concept. Far from selecting a repertoire of $\mathrm{T}$ cells that do not recognise self, the thymus selects a repertoire based upon recognition, albeit weakly, of peptides derived from self. Thus the repertoire of $\mathrm{T}$ cells that can subsequently recognise bacteria is heavily biased towards bacterial versions of conserved proteins, also present in man [80].

The role of heat shock proteins. The heat shock proteins (hsp) are important examples of this concept. Indeed the 
$65 \mathrm{kDa}$ heat shock protein of $M$. leprae can protect mice against M. tuberculosis [209], as can DNA vaccines based on its sequence. Nevertheless, there is one report that in the guinea-pig at least, immunisation with hsp may cause immunopathology in the lung, suggestive of autoimmunity, that is triggered when the aerosol infection with TB is subsequently given [210]. The importance of protective immunity of conserved proteins such as heat shock proteins has been emphasised repeatedly by others [211]. Not only are hsp important target antigens in their own right, but they also have a fundamental regulatory role. Thus hsp's can act as adjuvants, either used as purified protein, or when their encoding sequences are incorporated into DNA vaccines, encoding, for instance, papilloma virus antigen E7 [212]. They probably act as a danger signal. It is of great interest that during infection with Listeria monocytogenes there is increased membrane expression of mammalian hsp60, the homologue of hsp65 [213].

\section{The future}

\section{Immunotherapy}

This is perhaps the most important issue facing workers in the field of tuberculosis. As outlined earlier, DOTS helps, but fails to solve the problem, and multidrug-resistant disease is an increasing threat. Immunotherapy is the only solution, and the need for this approach has been recognised since the time of R. KoCH [214].

One potential approach to immunotherapy is the direct use of cytokines in patients, either systemically, or given by aerosol. IL-2, IFN $\gamma$, IL-12 and GM-CSF have all been investigated (reviewed in [215]). Their potential roles in therapy, other than as a potential adjunct to drug treatment in multiresistant cases, have yet to be elucidated.

Another approach that gives striking results in mice is the use of DHEA or of the very similar androstenediol. These compounds oppose a subset of the effects of glucocorticoids, and can reverse the switch towards Type 2 cytokine profile in Balb/c mice (fig. 5), but this has not been tested in man [184].

Immunotherapy is unlikely to be achieved by simple antigen preparations, because there needs to be an immunoregulatory component, with downregulation of pre-existing Type 2 cytokine production. This may explain why antigen preparations that can protect against tuberculosis when used as vaccines before challenge, can fail to act as therapeutics in mouse models [217].

Interestingly, the only preparations shown to be effective immunotherapeutics in tuberculous mice are killed Mycobacterium vaccae (fig. 5) [216, 218], and more recently DNA vaccines encoding common mycobacterial antigens [219].

Attempts at immunotherapy using an environmental saprophyte, $M$. vaccae, followed studies of the influence of such organisms on disease susceptibility and on the efficacy of BCG vaccination [102], a concept that is now widely accepted [103]. Since $M$. vaccae does not include the species-specific epitopes, induction of the necrotising Koch phenomenon is avoided, while the protective efficacy of multiple common antigens (including hsp's) can be exploited. Two studies of single injections of heat-killed $M$. vaccae have been carried out to Good Clinical Practice (GCP) in human tuberculosis patients also receiving DOTS. The results are conflicting [220, 221].

In view of the inevitable difficulty of demonstrating an effect when a single dose is superimposed upon a)

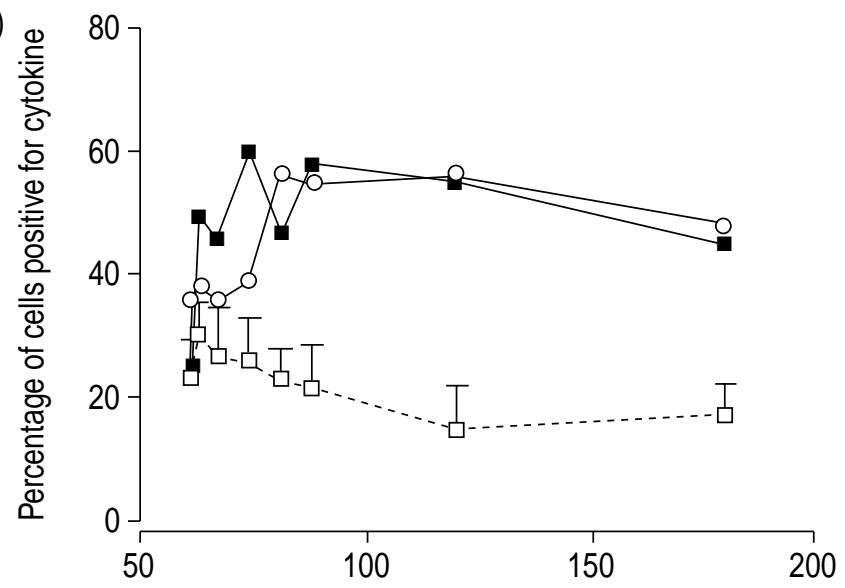

b)

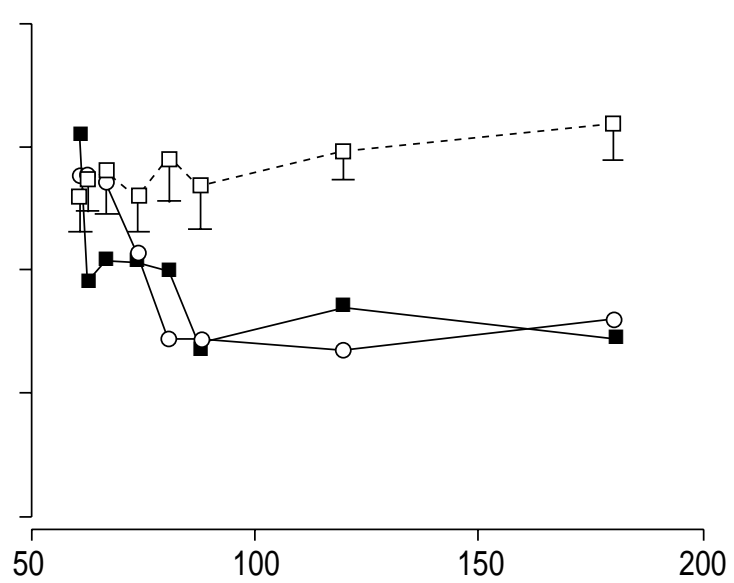

Days since intratracheal infection with M. tuberculosis H37Rv

Fig. 5. - Immunocytochemical analysis of cells positive for a) interleukin-2 (IL-2) and b) interleukin-4 (IL-4) in the areas of granuloma of the lungs of Balb/c mice infected with Mycobacterium tuberculosis H37Rv, and treated with the indicated regimen from day 60. Data are means of $12-18$ random fields (3 fields from each of 4-6 mice). Both immunotherapeutic regimens caused an increase in IL-2 positive cells, and a decrease in IL-4 positive cells. ( $\square$ ) control infected mice; ( $\bigcirc$ ) treated d60 and d90 with Mycobacterium vaccae $1.0 \mathrm{mg}$; $(\boldsymbol{\square})$ treated from $\mathrm{d} 60, \times 3 \cdot \mathrm{wee}^{-1}$ with androstenediol and a physiological replacement dose of corticosterone. Error bars on the control points are SD. They are omitted from the test groups for the sake of clarity, but are of similar size in these groups. Both test groups are significantly different from controls from day 88 (i.e. from 28 days after initiating immunotherapy $(\mathrm{p}<0.01))$. Adapted from [216]. 
DOTS, there is a clear need for a trial of multiple doses in multidrug resistant disease, as used in the pilot nonGCP studies in multidrug resistant TB [222]. M. vaccae has appropriate properties because, although it is used killed, it evokes not only Type 1 responses [223], and cytotoxic $\mathrm{CD}^{+} \mathrm{T}$ cells that kill target cells infected with M. tuberculosis [224], but also acts as a potent nonspecific downregulator of pre-existing $\mathrm{Th} 2$ responses both in mice [225], and in GCP studies in human asthmatics [226]. It can also induce Th1 recognition of common mycobacterial antigens in HIV $^{+}$individuals, which may prove to be an important requirement in developing countries [227].

\section{Creation of reliable diagnostic tests}

There have been numerous reviews of the many attempts to generate a reliable serodiagnostic test for tuberculosis [228]. No such tests currently exist because of the dual problems of cross-reactive background antibody evoked by ubiquitous environmental mycobacteria (and in some countries, by BCG), and individual differences in the specific epitopes recognised. The lymphoproliferative or IFN $\gamma$ response to certain low molecular weight culture filtrate antigens may distinguish between BCG vaccinated and tuberculosisinfected individuals [229], but such tests are cumbersome for field use.

\section{Exploitation of the genome sequence}

In 1998 the $4,411,529$ base pairs of the $M$. tuberculosis genome were published [230]. Of the 3924 protein encoding genes, only $40 \%$ strongly matched other known proteins, leaving the majority with no clear function. Access to this sequence has already permitted significant advances [231]. One example is the identification of four polyketide synthase systems. These have no known purpose but a product of these pathways may be a lipid toxin similar to that produced by $M$. ulcerans (the cause of Buruli ulcer) [150]. Other authors analysed the 3,924 protein-encoding sequences deduced from the $M$. tuberculosis genome, and identified 52 proteins carrying an aminoterminal secretory signal peptide, but lacking additional membraneanchoring moieties. Of these 52 proteins, only 7 had been previously reported to be secreted proteins [232]. Secreted proteins are good candidates as protective antigens.

Further genome sequencing is allowing the comparison of pathogenic with nonpathogenic mycobacteria, and virulent outbreak-causing strains (e.g. the "Oshkosh" strain) with less virulent strains. This may accelerate identification of crucial mechanisms of pathogenesis. Similarly the development of microarrays has facilitated the genotyping and comparison of BCG strains [233].

Evaluation of gene regulation, combined with analysis of the genome databases, allows identification of genes that are up- or down-regulated in response to environmental and other stimuli. For instance genes induced by exposure to isoniazid have been found [234].
The genome has also revealed several repetitive DNA sequences that were previously unidentified and these may prove useful in molecular typing.

\section{A role for mycobacteria in human health?}

The existence of CD1-restricted T cells that recognise mycobacterial glycolipids [65], and the ability of saprophytic environmental mycobacteria to kill children with defective receptors for interferon- $\gamma$ or interleukin-12 [42] suggest that these organisms are part of the evolutionary history of the human (and mammalian) immune system. Moreover these organisms are ubiquitous in soil and untreated water, but not a major part of the normal human commensal flora. Therefore, exposure to them is a variable that depends on lifestyle, and is decreasing in modern hygienic concrete environments. A decreasing exposure to mycobacteria has therefore begun to be highlighted as one explanation for the increasing incidence of diseases of immunoregulation such as allergies and autoimmunity [235]. There is some evidence that mycobacteria can be used therapeutically in the treatment of both [226, 236].

\section{References}

1. Kochi A. The global tuberculosis situation and the new control strategy of the World Health Organization. Tubercle 1991; 72: 1-6.

2. Hawken M, Nunn P, Gathua S, et al. Increased recurrence of tuberculosis in HIV-1-infected patients in Kenya. Lancet 1993; 342: $332-337$.

3. Spence DP, Hotchkiss J, Williams CS, Davies PD. Tuberculosis and poverty. Brit Med $J$ 1993; 307: 759 761.

4. Ityavyar DA. Health service inequalities in Nigeria. Soc Sci Med 1988; 27: 1223-1235.

5. Butler D. Consortium aims to kick-start TB research. Nature 2000; 403: 692.

6. Grange JM. The mystery of the mycobacterial persister. Tubercle Lung Dis 1992; 73: 249-251.

7. Siegele DA, Kolter R. Life after log. J Bacteriol 1992; 174: $345-348$.

8. Opie EL, Aronson JD. Tubercle bacilli in latent tuberculous lesions and in lung tissue without tuberculous lesions. Arch Pathol Lab Med 1927; 4: $1-21$.

9. Dhillon J, Allen BW, Hu YM, Coates AR, Mitchison DA. Metronidazole has no antibacterial effect in Cornell model murine tuberculosis. Int $J$ Tuberc Lung Dis 1998; 2: $736-742$.

10. Wayne LG. Dormancy of Mycobacterium tuberculosis and latency of disease. Eur J Clin Microbiol Infect Dis 1994; 13: $908-914$.

11. Dolin PJ, Raviglione MC, Kochi A. Global tuberculosis incidence and mortality during 1990-2000. Bull World Health Organ 1994; 72: 213-220.

12. van Rie A, Warren R, Richardson M, et al. Exogenous reinfection as a cause of recurrent tuberculosis after curative treatment. $N$ Engl J Med 1999; 341: $1174-$ 1179.

13. Fine PE, Small PM. Exogenous reinfection in tuberculosis. N Engl J Med 1999; 341: 1226-1227. 
14. Koch R. Fortsetzung Ÿber ein Heilmittel gegen Tuberculose. Deutsch Med Wochenschr 1891; 17: $101-102$.

15. Wilson GS, Schwabacher H, Maier I. The effect of the desensitisation of tuberculous guinea-pigs. $J$ Path Bact 1940; 50: $89-109$.

16. Balasubramanian R, Sivasubramanian S, Vijayan VK, et al. Five year results of a 3 month and two 5 month regimens for the treatment of sputum-positive pulmonary tuberculosis in South India. Tubercle 1990; 71: $253-258$.

17. Johnson CM, Cooper AM, Frank AA, Bonorino CB, Wysoki LJ, Orme IM. Mycobacterium tuberculosis aerogenic rechallenge infections in B cell-deficient mice. Tuber Lung Dis 1997; 78: 257-261.

18. Teitelbaum R, Glatman-Freedman A, Chen B, et al. A $\mathrm{mAb}$ recognizing a surface antigen of Mycobacterium tuberculosis enhances host survival. Proc Natl Acad Sci USA 1998; 95: $15688-15693$.

19. Glatman-Freedman A, Casadevall A. Serum therapy for tuberculosis revisited: reappraisal of the role of antibody-mediated immunity against Mycobacterium tuberculosis. Clin Microbiol Rev 1998; 11: 514-532.

20. Clerici M, Shearer GM. The Th1-Th2 hypothesis of HIV infection: new insights. Immunology Today 1994; 15: $575-581$

21. Salgame PR, Abrams JS, Clayberger C, et al. Differing lymphokine profiles of functional subsets of human CD4 and CD8 T cell clones. Science 1991; 254: 279 282.

22. Mosmann TR, Cherwinski H, Bond MW, Giedlin MA, Coffman RL. Two types of murine helper T cell clone. 1) Definition according to profiles of lymphokine activities and secreted proteins. J Immunol 1986; 136: $2348-2357$.

23. Ladel $\mathrm{CH}$, Daugelat $\mathrm{S}$, Kaufmann $\mathrm{SH}$. Immune response to Mycobacterium bovis bacille Calmette Guerin infection in major histocompatibility complex class I- and II-deficient knock-out mice: contribution of CD4 and CD8 T cells to acquired resistance. Eur J Immunol 1995; 25: 377-384.

24. Dalton DK, Pitts-Meek S, Keshav S, Figari IS, Bradley A, Stewart TA. Multiple defects of immune cell function in mice with disrupted interferon-gamma genes. Science 1993; 259: 1739-1742.

25. Cooper AM, Dalton DK, Stewart TA, Griffin JP, Russell DG, Orme IM. Disseminated tuberculosis in interferon gamma gene-disrupted mice. J Exp Med 1993; 178: $2243-2247$.

26. Flynn JL, Chan J, Triebold KJ, Dalton DK, Stewart TA, Bloom BR. An essential role for interferon gamma in resistance to Mycobacterium tuberculosis infection. $J$ Exp Med 1993; 178: 2249-2254.

27. Sugawara I, Yamada H, Kaneko H, Mizuno S, Takeda K, Akira S. Role of interleukin-18 (IL-18) in mycobacterial infection in IL-18-gene-disrupted mice. Infect Immun 1999; 67: 2585-2589.

28. Thompson SL, Skamene E, Radzioch D. Acquired resistance but not innate resistance to Mycobacterium bovis bacillus Calmette-Guerin is compromised by interleukin-12 ablation. Infect Immun 1998; 66: 5268 5274.

29. Wakeham J, Wang J, Magram J, et al. Lack of both types 1 and 2 cytokines, tissue inflammatory responses, and immune protection during pulmonary infection by Mycobacterium bovis bacille Calmette-Guerin in
IL-12-deficient mice. J Immunol 1998; 160: $6101-$ 6111.

30. Hernandez-Pando R, Pavon L, Arriaga K, Orozco H, Madrid-Marina V, Rook GAW. Pathogenesis of tuberculosis in mice exposed to low and high doses of an environmental mycobacterial saprophyte. Infect Immun 1997; 65: 3317-3327.

31. Hernandez-Pando R, Orozco H, Sampieri A, et al. Correlation between the kinetics of Th1/Th2 cells and pathology in a murine model of experimental pulmonary tuberculosis. Immunology 1996; 89: 26-33.

32. North RJ. Mice incapable of making IL-4 or IL-10 display normal resistance to infection with Mycobacterium tuberculosis. Clin Exp Immunol 1998; 113: $55-58$

33. Watson VE, Hill LL, Owen-Schaub L, et al. Apoptosis in mycobacterium tuberculosis infection in mice exhibiting varied immunopathology. J Pathol 2000; 190: $211-220$.

34. Johnson CM, Cooper AM, Frank AA, Orme IM. Adequate expression of protective immunity in the absence of granuloma formation in Mycobacterium tuberculosis-infected mice with a disruption in the intracellular adhesion molecule 1 gene. Infect Immun 1998; 66: 1666-1670.

35. Torres M, Herrera T, Villareal H, Rich EA, Sada E. Cytokine profiles for peripheral blood lymphocytes from patients with active pulmonary tuberculosis and healthy household contacts in response to the 30kilodalton antigen of Mycobacterium tuberculosis. Infect Immun 1998; 66: 176-180.

36. Wilkinson RJ, Wilkinson KA, De SK, et al. Human Tand $\mathrm{B}$-cell reactivity to the $16 \mathrm{kDa}$ alpha-crystallin protein of Mycobacterium tuberculosis. Scand J Immunol 1998; 48: 403 - 409.

37. Verbon A, Juffermans N, Van DS, et al. Serum concentrations of cytokines in patients with active tuberculosis (TB) and after treatment. Clin Exp Immunol 1999; 115: 110-113.

38. Bellamy R. Identifying genetic susceptibility factors for tuberculosis in africans: a combined approach using a candidate gene study and a genome-wide screen. Clin Sci (Colch) 2000; 98: 245-250.

39. Blackwell JM, Searle S. Genetic regulation of macrophage activation: understanding the function of Nramp1 (=Ity/Lsh/Bcg). Immunol Lett 1999; 65: $73-80$.

40. Wilkinson RJ, Llewelyn M, Toossi Z, et al. Influence of vitamin $\mathrm{D}$ deficiency and vitamin $\mathrm{D}$ receptor polymorphisms on tuberculosis among Gujarati Asians in west London: a case-control study. Lancet 2000; 355: $618-621$.

41. Jouanguy E, Altare F, Lamhamedi S, et al. Interferon$\gamma$ receptor deficiency in an infant with fatal Bacille Calmette-Guérin infection. New Engl J Med 1996; 335: $1956-1961$.

42. Newport M, Huxley CM, Huston S, et al. A mutation in the interferon- $\gamma$ receptor gene and susceptibility to mycobacterial infection. New Engl J Med 1996; 335: $1941-1949$.

43. Altare F, Durandy A, Lammas D, et al. Impairment of mycobacterial immunity in human interleukin-12 receptor deficiency. Science 1998; 280: 1432-1435.

44. de Jong R, Altare F, Haagen IA, et al. Severe mycobacterial and Salmonella infections in interleukin-12 receptor-deficient patients. Science 1998; 280: $1435-$ 1438. 
45. Flynn JL, Goldstein MM, Triebold KJ, Koller B, Bloom BR. Major histocompatibility complex class Irestricted $\mathrm{T}$ cells are required for resistance to Mycobacterium tuberculosis infection. Proc Natl Acad Sci USA 1992; 89: 12013-12017.

46. Leveton C, Barnass S, Champion B, et al. T-cellmediated protection of mice against virulent Mycobacterium tuberculosis. Infect Immun 1989; 57: $390-395$.

47. Bonato VL, Lima VM, Tascon RE, Lowrie DB, Silva CL. Identification and characterization of protective T cells in hsp65 DNA-vaccinated and Mycobacterium tuberculosis-infected mice. Infect Immun 1998; 66: $169-175$.

48. Mazzaccaro RJ, Stenger S, Rock KL, et al. Cytotoxic T lymphocytes in resistance to tuberculosis. Adv Exp Med Biol 1998; 452: 85-101.

49. Teitelbaum R, Cammer M, Maitland ML, Freitag NE, Condeelis J, Bloom BR. Mycobacterial infection of macrophages results in membrane-permeable phagosomes. Proc Natl Acad Sci USA 1999; 96: 1519015195.

50. Canaday DH, Ziebold C, Noss EH, Chervenak KA, Harding CV, Boom WH. Activation of human CD8 + alpha beta TCR + cells by Mycobacterium tuberculosis via an alternate class I MHC antigen-processing pathway. J Immunol 1999; 162: 372-379.

51. Wren BW, Stabler RA, Das SS, et al. Characterization of a haemolysin from Mycobacterium tuberculosis with homology to a virulence factor of Serpulina hyodysenteriae. Microbiology 1998; 1205-1211.

52. Hess J, Miko D, Catic A, Lehmensiek V, Russell DG, Kaufmann SH. Mycobacterium bovis Bacille CalmetteGuerin strains secreting listeriolysin of Listeria monocytogenes. Proc Natl Acad Sci USA 1998; 95: $5299-5304$.

53. Stenger S, Hanson DA, Teitelbaum R, et al. An antimicrobial activity of cytolytic $\mathrm{T}$ cells mediated by granulysin. Science 1998; 282: $121-125$.

54. Fazal N, Lammas DA, Rahelu M, Pithie AD, Gaston JS, Kumararatne DS. Lysis of human macrophages by cytolytic CD4 $+\mathrm{T}$ cells fails to affect survival of intracellular Mycobacterium bovis-bacille CalmetteGuerin (BCG). Clin Exp Immunol 1995; 99: 82-89.

55. Cooper AM, D'Souza C, Frank AA, Orme IM. The course of Mycobacterium tuberculosis infection in the lungs of mice lacking expression of either perforin- or granzyme-mediated cytolytic mechanisms. Infect Immun 1997; 65: $1317-1320$.

56. Laochumroonvorapong $\mathrm{P}$, Wang $\mathrm{J}$, Liu $\mathrm{CC}$, et al. Perforin, a cytotoxic molecule which mediates cell necrosis, is not required for the early control of mycobacterial infection in mice. Infect Immun 1997; 65: $4850-4857$.

57. Tascon RE, Stavropoulos E, Lukacs KV, Colston MJ. Protection against Mycobacterium tuberculosis infection by $\mathrm{CD} 8+\mathrm{T}$ cells requires the production of gamma interferon. Infect Immun 1998; 66: 830-834.

58. Serbina NV, Flynn JL. Early emergence of CD $8(+)$ $\mathrm{T}$ cells primed for production of type 1 cytokines in the lungs of Mycobacterium tuberculosis-infected mice. Infect Immun 1999; 67: 3980-3988.

59. Lalvani A, Brookes R, Wilkinson RJ, et al. Human cytolytic and interferon gamma-secreting CD8 $+\mathrm{T}$ lymphocytes specific for Mycobacterium tuberculosis. Proc Natl Acad Sci USA 1998; 95: 270-275.

60. Tan JS, Canaday DH, Boom WH, Balaji KN,
Schwander SK, Rich EA. Human alveolar T lymphocyte responses to Mycobacterium tuberculosis antigens: role for CD4+ and CD8 + cytotoxic T cells and relative resistance of alveolar macrophages to lysis. J Immunol 1997; 159: 290-297.

61. Lewinsohn DM, Alderson MR, Briden AL, Riddell SR, Reed SG, Grabstein KH. Characterization of human CD8 $+\mathrm{T}$ cells reactive with Mycobacterium tuberculosis-infected antigen-presenting cells. $J$ Exp Med 1998; 187: 1633 - 1640.

62. Silver RF, Li Q, Boom WH, Ellner JJ. Lymphocytedependent inhibition of growth of virulent Mycobacterium tuberculosis $\mathrm{H} 37 \mathrm{Rv}$ within human monocytes: requirement for CD4 $+\mathrm{T}$ cells in purified protein derivative-positive, but not in purified protein derivative-negative subjects. J Immunol 1998; 160: 2408 - 2417.

63. Gong J, Stenger S, Zack JA, et al. Isolation of mycobacterium-reactive CD1-restricted $\mathrm{T}$ cells from patients with human immunodeficiency virus infection. J Clin Invest 1998; 101: 383-389.

64. Stenger S, Mazzaccaro RJ, Uyemura $\mathrm{K}$, et al. Differential effects of cytolytic $\mathrm{T}$ cell subsets on intracellular infection. Science 1997; 276: 1684-1687.

65. Porcelli SA, Modlin RL. The CD1 system: antigenpresenting molecules for $\mathrm{T}$ cell recognition of lipids and glycolipids. Annu Rev Immunol 1999; 17: 297 - 329.

66. Rosat JP, Grant EP, Beckman EM, et al. CD1restricted microbial lipid antigen-specific recognition found in the CD8 + alpha beta T cell pool. J Immunol 1999; 162: 366-371.

67. Behar SM, Dascher CC, Grusby MJ, Wang CR, Brenner MB. Susceptibility of mice deficient in CD1D or TAP1 to infection with Mycobacterium tuberculosis. J Exp Med 1999; 189: 1973-1980.

68. Szalay G, Zugel U, Ladel CH, Kaufmann SH. Participation of group $2 \mathrm{CD} 1$ molecules in the control of murine tuberculosis. Microbes Infect 1999; 1: $1153-1157$.

69. Beckman EM, Porcelli SA, Morita CT, Behar SM, Furlong ST, Brenner MB. Recognition of a lipid antigen by CD1-restricted alpha beta $+\mathrm{T}$ cells. Nature 1994; 372: 691-694.

70. Moody DB, Reinhold BB, Guy MR, et al. Structural requirements for glycolipid antigen recognition by CD1b- restricted T cells. Science 1997; 278: 283-286.

71. Sieling PA, Chatterjee D, Porcelli SA, et al. CD1restricted $\mathrm{T}$ cell recognition of microbial lipoglycan antigens. Science 1995; 269: $227-230$.

72. Stenger S, Niazi KR, Modlin RL. Down-regulation of CD1 on antigen-presenting cells by infection with Mycobacterium tuberculosis. J Immunol 1998; 161: $3582-3588$.

73. Follows GA, Munk ME, Gatrill AJ, Conradt P, Kaufmann SH. Gamma interferon and interleukin 2, but not interleukin 4, are detectable in gamma/delta Tcell cultures after activation with bacteria. Infect Immun 1992; 60: 1229 - 1231.

74. Boom WH, Chervenak KA, Mincek MA, Ellner JJ. Role of the mononuclear phagocyte as an antigenpresenting cell for human $\gamma / \delta$ T cells activated by live Mycobacterium tuberculosis. Infect Immun 1992; 60: $3480-3488$.

75. Boom WH, Balaji KN, Nayak R, Tsukaguchi K, Chervenak KA. Characterization of a 10- to 14kilodalton protease-sensitive Mycobacterium tuberculosis H37Ra antigen that stimulates human 
gamma delta T cells. Infect Immun 1994; 62: $5511-$ 5518.

76. Pfeffer K, Schoel B, Gulle H, Kaufmann SH, Wagner $H$. Primary responses of human $T$ cells to mycobacteria: a frequent set of gamma/delta $T$ cells are stimulated by protease-resistant ligands. Eur J Immunol 1990; 20: 1175-1179.

77. Tanaka Y, Morita CT, Tanaka Y, Nieves E, Brenner MB, Bloom BR. Natural and synthetic non-peptide antigens recognized by human gamma delta $\mathrm{T}$ cells. Nature 1995; 375: 155-158.

78. Griffin JP, Harshan KV, Born WK, Orme IM. Kinetics of accumulation of gamma delta receptorbearing $\mathrm{T}$ lymphocytes in mice infected with live mycobacteria. Infect Immun 1991; 59: 4263-4265.

79. Tsukaguchi K, Balaji KN, Boom WH. CD4+ alpha beta $\mathrm{T}$ cell and gamma delta $\mathrm{T}$ cell responses to Mycobacterium tuberculosis. Similarities and differences in $\mathrm{Ag}$ recognition, cytotoxic effector function, and cytokine production. J Immunol 1995; 154 $1786-1796$.

80. Ladel CH, Blum C, Dreher A, Reifenberg K, Kaufmann SH. Protective role of gamma/delta T cells and alpha/beta $\mathrm{T}$ cells in tuberculosis [published erratum appears in Eur $J$ Immunol 1995 Dec; 25(12):3525]. Eur J Immunol 1995; 25: 2877-2881.

81. D'Souza CD, Cooper AM, Frank AA, Mazzaccaro RJ, Bloom BR, Orme IM. An anti-inflammatory role for gamma delta $\mathrm{T}$ lymphocytes in acquired immunity to Mycobacterium tuberculosis. J Immunol 1997; 158: $1217-1221$

82. Li B, Rossman MD, Imir $\mathrm{T}$, et al. Disease-specific changes in gammadelta $\mathrm{T}$ cell repertoire and function in patients with pulmonary tuberculosis. $J$ Immunol 1996; 157: 4222-4229.

83. Behr Perst SI, Munk ME, Schaberg T, Ulrichs $\mathrm{T}$, Schulz RJ, Kaufmann SH. Phenotypically activated gammadelta $\mathrm{T}$ lymphocytes in the peripheral blood of patients with tuberculosis. J Infect Dis 1999; 180: 141 149.

84. Li B, Bassiri H, Rossman MD, et al. Involvement of the Fas/Fas ligand pathway in activation-induced cell death of mycobacteria-reactive human gamma delta $T$ cells: a mechanism for the loss of gamma delta $\mathrm{T}$ cells in patients with pulmonary tuberculosis. J Immunol 1998; 161: $1558-1567$.

85. Manfredi AA, Heltai S, Rovere $\mathrm{P}$, et al. Mycobacterium tuberculosis exploits the CD95/CD95 ligand system of gammadelta $\mathrm{T}$ cells to cause apoptosis. Eur J Immunol 1998; 28: 1798 - 1806.

86. Hirsch CS, Toossi Z, Vanham G, et al. Apoptosis and $\mathrm{T}$ cell hyporesponsiveness in pulmonary tuberculosis. J Infect Dis 1999; 179: 945-953.

87. Das G, Vohra H, Saha B, Agrewala JN, Mishra GC. Apoptosis of Th1-like cells in experimental tuberculosis (TB). Clin Exp Immunol 1999; 115: $324-328$

88. Varadhachary AS, Salgame P. CD95 mediated T cell apoptosis and its relevance to immune deviation. Oncogene 1998; 17: $3271-3276$.

89. Seah GT, Scott GM, Rook GA. Type 2 Cytokine Gene Activation and Its Relationship to Extent of Disease in Patients with Tuberculosis. J Infect Dis 2000; 181: 385-389.

90. van Crevel R, Karyadi E, Preyers F, et al. Increased Production of Interleukin 4 by CD $4+$ and CD $8+$ $\mathrm{T}$ Cells from Patients with Tuberculosis Is Related to the Presence of Pulmonary Cavities. J Infect Dis 2000; 181: $1194-1197$.

91. Seah GT, Rook GA. A sensitive, non-radioactive quantitative method for measuring IL-4 and IL4delta2 mRNA in unstimulated cells from multiple clinical samples, using nested RT-PCR. J Immunol Methods 1999; 228: 139-149.

92. Yong AJ, Grange JM, Tee RD, et al. Total and antimycobacterial IgE levels in serum from patients with tuberculosis and leprosy. Tubercle 1989; 70: 273-279.

93. Wilsher ML, Hagan C, Prestidge R, Wells AU, Murison G. Human in vitro immune responses to Mycobacterium tuberculosis. Tuber Lung Dis 1999; 79: $371-377$.

94. Bergeron A, Bonay M, Kambouchner M, et al. Cytokine patterns in tuberculous and sarcoid granulomas. J Immunol 1997; 159: 3034 - 3043.

95. Schauf V, Rom WN, Smith KA, et al. Cytokine gene activation and modified responsiveness to interleukin2 in the blood of tuberculosis patients. J Infect Dis 1993; 168: 1056-1059.

96. Zhang M, Lin Y, Iyer DV, Gong J, Abrams J, Barnes $\mathrm{P}$. T cell cytokine responses in human infection with Mycobacterium tuberculosis. Infect Immun 1995; 63: $3231-3234$

97. Arinobu Y, Atamas SP, Otsuka T, et al. Antagonistic effects of an alternative splice variant of human IL-4, IL-4 delta 2, on IL-4 activities in human monocytes and B cells. Cell Immunol 1999; 191: $161-167$.

98. Rook GA, Carswell JW, Stanford JL. Preliminary evidence for the trapping of antigen-specific lymphocytes in the lymphoid tissue of 'anergic' tuberculosis patients. Clin Exp Immunol 1976; 26: $129-132$.

99. Dieli F, Friscia G, Di SC, et al. Sequestration of T lymphocytes to body fluids in tuberculosis: reversal of anergy following chemotherapy. J Infect Dis 1999; 180: $225-228$.

100. Hernandez-Pando R, Rook GAW. The role of TNF $\alpha$ in T cell-mediated inflammation depends on the Th1/ Th2 cytokine balance. Immunology 1994; 82: 591 - 595 .

101. Bretscher PA, Wei G, Menon JN, Bielefeldt-Ohmann $\mathrm{H}$. Establishment of stable, cell-mediated immunity that makes "susceptible" mice resistant to Leishmania major. Science 1992; 257: 539-542.

102. Stanford JL, Shield MJ, Rook GAW. How environmental mycobacteria may predetermine the protective efficacy of BCG. Tubercle 1981; 62: 55-62.

103. Fine PE. Variation in protection by BCG: implications of and for heterologous immunity. Lancet 1995; 346 : $1339-1345$.

104. van-der-Pouw-Kraan TC, Boeije LC, Smeenk RJ, Wijdenes J, Aarden LA. Prostaglandin-E2 is a potent inhibitor of human interleukin 12 production. $J$ Exp Med 1995; 181: 775-779.

105. Hilkens CM, Vermeulen $\mathrm{H}$, van-Neerven RJ, Snijdewint FG, Wierenga EA, Kapsenberg ML. Differential modulation of T helper type 1 (Th1) and $\mathrm{T}$ helper type 2 (Th2) cytokine secretion by prostaglandin E2 critically depends on interleukin-2. Eur J Immunol 1995; 25: 59-63.

106. Ellner JJ. Regulation of the human immune response during tuberculosis. J Lab Clin Med 1997; 130: 469 475 .

107. Hernandez-Pando R, Orozco H, Arriaga K, Sampieri A, Larriva SJ, Madrid MV. Analysis of the local kinetics and localisation of interleukin $1 \alpha$ tumour 
necrosis factor $\alpha$ and transforming growth factor $\beta$ during the course of experimental pulmonary tuberculosis. Immunology 1997; 90: 507-516.

108. Flynn JL, Goldstein MM, Chan J, et al. Tumor necrosis factor-alpha is required in the protective immune response against Mycobacterium tuberculosis in mice. Immunity 1995; 2: $561-572$.

109. Adams LB, Mason CM, Kolls JK, Scollard D, Krahenbuhl JL, Nelson S. Exacerbation of acute and chronic murine tuberculosis by administration of a tumour necrosis factor receptor-expressing adenovirus. J Infect Dis 1995; 171: 400-405.

110. Schlesinger LS. Mycobacterium tuberculosis and the complement system. Trends Microbiol 1998; 6: 47-9; $49-50$.

111. Kang BK, Schlesinger LS. Characterization of mannose receptor-dependent phagocytosis mediated by Mycobacterium tuberculosis lipoarabinomannan. Infect Immun 1998; 66: 2769-2777.

112. Shepard CC. A comparison of the growth of selected mycobacteria in HeLa, monkey kidney, and human amnion cells in tissue culture. J Exp Med 1958; 107 : $237-246$.

113. Filley EA, Rook GAW. Effect of mycobacteria on sensitivity to the cytotoxic effects of tumor necrosis factor. Infect Immun 1991; 59: 2567-2572.

114. Astarie-Dequeker C, N'Diaye EN, Le Cabec V, Rittig MG, Prandi J, Maridonneau-Parini I. The mannose receptor mediates uptake of pathogenic and nonpathogenic mycobacteria and bypasses bactericidal responses in human macrophages. Infect Immun 1999; 67: $469-477$.

115. Means TK, Lien E, Yoshimura A, Wang S, Golenbock DT, Fenton MJ. The CD14 ligands lipoarabinomannan and lipopolysaccharide differ in their requirement for Toll-like receptors. J Immunol 1999; 163: $6748-6755$.

116. Means TK, Wang S, Lien E, Yoshimura A, Golenbock DT, Fenton MJ. Human toll-like receptors mediate cellular activation by Mycobacterium tuberculosis. J Immunol 1999; 163: 3920-3927.

117. Brightbill HD, Libraty DH, Krutzik SR, et al. Host defense mechanisms triggered by microbial lipoproteins through toll-like receptors. Science 1999; 285: $732-736$.

118. Rook GAW, Steele J, Fraher L, et al. Vitamin D3, gamma interferon, and control of proliferation of Mycobacterium tuberculosis by human monocytes. Immunology 1986; 57: 159-163.

119. Rook GAW, Champion BR, Steele J, Varey AM, Stanford JL. I-A restricted activation by T cell lines of anti-tuberculosis activity in murine macrophages. Clin Exp Immunol 1985; 59: 414-420.

120. Hirsch CS, Ellner JJ, Russell DG, Rich EA. Complement receptor mediated uptake and Tumour Necrosis Factor $\alpha$-mediated growth inhibition of Mycobacterium tuberculosis by human alveolar macrophages. J Immunol 1994; 152: $743-753$.

121. Chan J, Xing Y, Magliozzo RS, Bloom BR. Killing of virulent Mycobacterium tuberculosis by reactive nitrogen intermediates produced by activated murine macrophages. J Exp Med 1992; 175: 1111-1122.

122. Chan J, Tanaka K, Carroll D, Flynn J, Bloom BR. Effects of nitric oxide synthase inhibitors on murine infection with Mycobacterium tuberculosis. Infect Immun 1995; 63: 736-740.

123. Roach TIA, Chatterjee D, Blackwell JM. Induction of early-response genes $\mathrm{KC}$ and JE by mycobacterial lipoarabinomannans: regulation of $\mathrm{KC}$ expression in murine macrophages by Lsh/Ity/Bcg (candidate Nramp). Infect Immun 1994; 62: 1176-1184.

124. Adams LB, Dinauer MC, Morgenstern DE, Krahenbuhl JL. Comparison of the roles of reactive oxygen and nitrogen intermediates in the host response to Mycobacterium tuberculosis using transgenic mice. Tuber Lung Dis 1997; 78: 237-246.

125. Gomes MS, Florido M, Pais TF, Appelberg R. Improved clearance of Mycobacterium avium upon disruption of the inducible nitric oxide synthase gene. J Immunol 1999; 162: 6734-6739.

126. Nicholson S, Bonecini, Almeida MdG, et al. Inducible nitric oxide synthase in pulmonary alveolar macrophages from patients with tuberculosis. $J$ Exp Med 1996; 183: 2293 - 2302.

127. Nozaki Y, Hasegawa Y, Ichiyama S, Nakashima I, Shimokata K. Mechanism of nitric oxide-dependent killing of Mycobacterium bovis BCG in human alveolar macrophages. Infect Immun 1997; 65: $3644-$ 3647.

128. Wang $\mathrm{CH}$, Liu $\mathrm{CY}$, Lin $\mathrm{HC}$, Yu CT, Chung KF, Kuo HP. Increased exhaled nitric oxide in active pulmonary tuberculosis due to inducible NO synthase upregulation in alveolar macrophages. Eur Respir $J$ 1998; 11: 809-815.

129. Aston C, Rom WN, Talbot AT, Reibman J. Early inhibition of mycobacterial growth by human alveolar macrophages is not due to nitric oxide. Am J Respir Crit Care Med 1998; 157: 1943 - 1950.

130. Rockett KA, Brookes R, Udalova I, Vidal V, Hill AVS, Kwiatkowski D. 1,25-dihydroxyvitamin D3 induces nitric oxide synthase and suppresses growth of Mycobacterium tuberculosis in a human macrophgelike cell line. Infect Immun 1998; 66: 5314-5321.

131. Klingler K, Tchou-Wong K, Brandli O, et al. Effects of mycobacteria on regulation of apoptosis in mononuclear phagocytes. Infect Immun 1997; 65: $5272-5278$.

132. Rojas M, Barrera LF, Puzo G, Garcia LF. Differential induction of apoptosis by virulent Mycobacterium tuberculosis in resistant and susceptible murine macrophages: role of nitric oxide and mycobacterial products. J Immunol 1997; 159: 1352-1361.

133. Keane J, Balcewicz SM, Remold HG, et al. Infection by Mycobacterium tuberculosis promotes human alveolar macrophage apoptosis. Infect Immun 1997; 65: $298-304$.

134. Oddo M, Renno T, Attinger A, Bakker T, MacDonald HR, Meylan PR. Fas ligand-induced apoptosis of infected human macrophages reduces the viability of intracellular Mycobacterium tuberculosis. J Immunol 1998; 160: $5448-5454$.

135. Molloy AP, Laochumroonvorapong P, Kaplan G. Apoptosis but not necrosis of infected monocytes is coupled with killing of intracellular Bacille CalmetteGuerin. J Exp Med 1994; 180: 1499.

136. Kusner DJ, Adams J. ATP-induced killing of virulent Mycobacterium tuberculosis within human macrophages requires phospholipase D. J Immunol 2000; 164: $379-388$.

137. Lammas DA, Stober C, Harvey CJ, Kendrick N, Panchalingam S, Kumararatne DS. ATP-induced killing of mycobacteria by human macrophages is mediated by purinergic $\mathrm{P} 2 \mathrm{Z}(\mathrm{P} 2 \mathrm{X} 7)$ receptors. Immunity 1997; 7: 433-444. 
138. Lauchumroonvorapong P, Paul S, Elkon KB, Kaplan $\mathrm{G} . \mathrm{H} 2 \mathrm{O} 2$ induces monocyte apoptosis and reduces viability of Mycobacterium avium- $M$. intracellulare within cultured human monocytes. Infect Immun 1996; 64: $452-459$.

139. Fratazzi C, Arbeit RD, Carini C, et al. Macrophage apoptosis in mycobacterial infections. J Leukoc Biol 1999; 66: $763-764$.

140. Chan J, Fan X, Hunter SW, Brennan PJ, Bloom BR. Lipoarabinomannan, a possible virulence factor involved in persistence of Mycobacterium tuberculosis within macrophages. Infect Immun 1991; 59: 17551761.

141. Malik ZA, Denning GM, Kusner DJ. Inhibition of $\mathrm{Ca}(2+)$ signaling by Mycobacterium tuberculosis is associated with reduced phagosome-lysosome fusion and increased survival within human macrophages. J Exp Med 2000; 191: 287-302.

142. Sturgill-Koszycki S, Schlesinger PH, Chakraborty P, et al. Lack of acidification in Mycobacterium phagosomes produced by exclusion of the vesicular proton-ATPase. Science 1994; 263: 678-681.

143. Xu S, Cooper A, Sturgill-Koszycki S, et al. Intracellular trafficking in Mycobacterium tuberculosis and Mycobacterium avium-infected macrophages. $J$ Immunol 1994; 153: 2568 - 2578.

144. Ilangumaran S, Arni S, Poincelet M, et al. Integration of mycobacterial lipoarabinomannans into glycosylphosphatidylinositol-rich domains of lymphomonocytic cell plasma membranes. J Immunol 1995; 155: $1334-1342$.

145. Pancholi P, Mirza A, Bhardwaj N, Steinman RM. Sequstration from immune CD4 $+\mathrm{T}$ cells of mycobacteria growing in human macrophages. Science 1993; 260: $984-986$.

146. Nandan D, Knutson KL, Lo R, Reiner NE. Exploitation of host cell signaling machinery: activation of macrophage phosphotyrosine phosphatases as a novel mechanism of molecular microbial pathogenesis. J Leukoc Biol 2000; 67: 464-470.

147. Fulton SA, Cross JV, Toossi ZT, Boom WH. Regulation of interleukin-12 by interleukin-10, transforming growth factor-beta, tumor necrosis factor-alpha, and interferon-gamma in human monocytes infected with Mycobacterium tuberculosis H37Ra. J Infect Dis 1998; 178: 1105-1114.

148. Toossi Z, Mincek M, Seeholtzer E, Fulton SA, Hamilton BD, Hirsch CS. Modulation of IL-12 by transforming growth factor-beta (TGF-beta) in Mycobacterium tuberculosis-infected mononuclear phagocytes and in patients with active tuberculosis. J Clin Lab Immunol 1997; 49: 59-75.

149. Balcewicz-Sablinska MK, Keane J, Kornfeld $\mathrm{H}$, Remold HG. Pathogenic Mycobacterium tuberculosis evades apoptosis of host macrophages by release of TNF-R2, resulting in inactivation of TNF-alpha. J Immunol 1998; 161: 2636-2641.

150. George KM, Chatterjee D, Gunawardana G, et al. Mycolactone: a polyketide toxin from Mycobacterium ulcerans required for virulence. Science 1999; 283: $854-857$.

151. Filley EA, Bull HA, Dowd PM, Rook GAW. The effect of Mycobacterium tuberculosis on the susceptibility of human cells to the stimulatory and toxic effects of Tumour Necrosis Factor. Immunology 1992; 77: $505-509$.
152. Anderson MC. On Koch's treatment. Lancet 1891; i: $651-652$.

153. Shwartzman G. Phenomenon of local tissue reactivity and its immunological, pathological, and clinical significance. Paul B Hoeber 1937; New York: 461.

154. Bordet $\mathrm{P}$. Contribution à $\mathrm{l}^{\prime}$ etude de $\mathrm{l}^{\prime}$ allergie. $C R$ Soc Biol 1931; 107: 622-623.

155. Debonera G, Tzortakis N, Falchetti E. Inflammation et phenomene de Shwartzman. C R Soc Biol 1932; 109: $24-26$.

156. Shands JW, Senterfitt VC. Endotoxin-induced hepatic damage in BCG-infected mice. Am J Pathol 1972; 67: $23-40$.

157. Nagao S, Tanaka A. Necrotic inflammatory reaction induced by muramyl dipeptide in guinea-pigs sensitized by tubercle bacilli. J Exp Med 1985; 162: $401-412$.

158. Hernandez-Pando R, Orozco H, Honour JP, Silva J, Leyva R, Rook GAW. Adrenal changes in murine pulmonary tuberculosis; a clue to pathogenesis? FEMS Immunol Med Microbiol 1995; 12: 63-72.

159. Orme IM, Roberts AD, Griffin JP, Abrams JS. Cytokine secretion by CD4 T lymphocytes acquired in response to Mycobacterium tuberculosis infection. J Immunol 1993; 151: 518 - 525.

160. Lawrence CE, Paterson JC, Higgins LM, MacDonald TT, Kennedy MW, Garside P. IL-4-regulated enteropathy in an intestinal nematode infection. Eur J Immunol 1998; 28: $2672-2684$.

161. Muller KM, Jaunin F, Masouye I, Saurat JH, Hauser C. Th2 cells mediate IL-4-dependent local tissue inflammation. J Immunol 1993; 150: 5576-5584.

162. Muller KM, Lisby S, Arrighi J, Grau GE, Saurat J, Hauser C. H-2D haplotype-linked expression and involvement of TNF- $\alpha$ in Th2 cell-mediated tissue inflammation. $J$ Immunol 1994; 153: 316-324.

163. Bekker L, Maartens G, Steyn L, Kaplan G. Selective increase in plasma tumour necrosis factor- $\alpha$ and concomitant clinical deterioration after initiating therapy in patients with severe tuberculosis. $J$ Infect Dis 1998; 178: 580 - 584 .

164. Haslett PA. Anticytokine approaches to the treatment of anorexia and cachexia. Semin Oncol 1998; 25: 53 57.

165. Moreira AL, Sampaio EP, Zmuidzinas A, Frindt P, Smith KA, Kaplan G. Thalidomide exerts its inhibitory action on tumor necrosis factor alpha by enhancing mRNA degradation. J Exp Med 1993; 177: $1675-1680$.

166. Tramontana JM, Utaipat U, Molloy A, et al. Thalidomide treatment reduces tumor necrosis factor alpha production and enhances weight gain in patients with pulmonary tuberculosis. Mol Med 1995; 1: $384-$ 397.

167. Rook GAW. The role of vitamin D in Tuberculosis (Editorial). Am Rev Resp Dis 1988; 138: 768-770.

168. Rigby WF, Yirinec B, Oldershaw RL, Fanger MW. Comparison of the effects of 1,25-dihydroxyvitamin D3 on T lymphocyte subpopulations. Eur J Immunol 1987; 17: $563-566$

169. Daynes RA, Meikle AW, Araneo BA. Locally active steroid hormones may facilitate compartmentalization of immunity by regulating the types of lymphokines produced by helper T cells. Res Immunol 1991; 142: $40-45$.

170. Lemire J, Beck L, Faherty D, Gately MK, Spiegelberg HL. 1,25-dihydroxyvitamin D3 inhibits the production 
of IL-12 by human monocytes and B cells. Steroid Biochem ol Biol 1995; 53: 599-602.

171. Veyron P, Pamphile R, Binderup L, Touraine JL. New 20-epi-vitamin D3 analogs: immunosuppressive effects on skin allograft survival. Transplant Proc 1995; 27: 450 .

172. Macrae DE. Calciferol treatment of Lupus vulgaris. Brit Med J 1947; 59: 333-338.

173. Brincourt $\mathbf{J}$. Le calciférol a-t-il une action liquéfiante sur le caseum? Poumon Coeur 1967; 23: 841 -851.

174. Ramirez F, Fowell DJ, Puklavec M, Simmonds S, Mason D. Glucocorticoids promote a Th2 cytokine response by CD4+ T cells in vitro. J Immunol 1996; 156: $2406-2412$.

175. Brinkmann V, Kristofic C. Regulation by corticosteroids of Th1 and Th2 cytokine production in human $\mathrm{CD} 4+$ effector $\mathrm{T}$ cells generated from CD45RO- and CD45RO + subsets. J Immunol 1995; 155: $3322-3328$

176. Vieira PL, Kalinski P, Wierenga EA, Kapsenberg ML, de Jong E. Glucocorticoids inhibit bioactive IL12 p70 production by in vitro-generated human dendritic cells without affecting their $\mathrm{T}$ cell stimulatory potential. J Immunol 1998; 161: 5245-5251.

177. Visser J, van Boxel-Dezaire A, Methorst D, Brunt T, de Kloet ER, Nagelkerken L. Differential regulation of interleukin-10 (IL-10) and IL-12 by glucocorticoids in vitro. Blood 1998; 91: 4255-4264.

178. Fischer A, Konig W. Influence of cytokines and cellular interactions on the glucocorticoid-induced Ig (E, G, A, M) synthesis of peripheral blood mononuclear cells. Immunology 1991; 74: 228-233.

179. Rook GA, Steele J, Ainsworth M, Leveton C. A direct effect of glucocorticoid hormones on the ability of human and murine macrophages to control the growth of M. tuberculosis. Eur J Respir Dis 1987; 71: 286 291.

180. Rook GAW, Hernandez-Pando R. The influence of adrenal steroids on macropage and $\mathrm{T}$ cell function. In: Paradise LJ, Friedman H, Bendinelli M, eds. Opportunistic Intracellular Bacteria and Immunity. New York: Plenum Press, 1999: 55-73. (Bendinelli M, Friedman $\mathrm{H}$, eds. Infectious agents and pathogenesis.)

181. Tobach E, Bloch H. Effect of stress by crowding prior to and following tuberculous infection. Am J Physiol 1956; 187: 399-402.

182. Brown DH, LaFuse W, Zwilling BS. Cytokinemediated activation of macrophages from $\mathrm{Myco}-$ bacterium bovis BCG-resistant and -susceptible mice: differential effects of corticosterone on antimycobacterial activity and expression of the Bcg gene (candidate Nramp). Infect Immun 1995; 63: $2983-2988$

183. Hernandez-Pando R, de la Luz Streber M, Orozco H, et al. The effects of androstenediol and dehydroepiandrosterone on the course and cytokine profile of tuberculosis in Balb/c mice. Immunology 1998; 95: $234-241$.

184. Hernandez-Pando R, de la Luz Streber M, Orozco H, et al. Emergent therapeutic properties of a combination of glucocorticoid and anti-glucocorticoid steroids in tuberculous Balb/c mice. Q J Med 1998; 91: $755-766$.

185. Sarma GR, Chandra I, Ramachandran G, Krishnamurthy PV, Kumaraswami V, Prabhakar R. Adrenocortical function in patients with pulmonary tuberculosis. Tubercle 1990; 71: 277-282.
186. Post FA, Soule SG, Willcox PA, Levitt NS. The spectrum of endocrine dysfunction in active pulmonary tuberculosis. Clin Endocrinol 1994; 40: $367-371$.

187. Rook G, Baker R, Walker B, et al. Local regulation of glucocorticoid activity in sites of inflammation; insights from the study of tuberculosis. Ann $N Y$ Acad Sci 2000; 917: 913-922.

188. Rook GAW, Honour J, Kon OM, Wilkinson RJ, Davidson R, Shaw RJ. Urinary steroid metabolites in tuberculosis; a new clue to pathogenesis. $Q \mathrm{~J} \mathrm{Med}$ 1996; 89: 333-341.

189. Tetsuka M, Thomas FJ, Thomas MJ, Anderson RA, Mason JI, Hillier SG. Differential expression of messenger ribonucleic acids encoding 11 betahydroxysteroid dehydrogenase types 1 and 2 in human granulosa cells. J Clin Endocrinol Metab 1997; 82: 2006-2009.

190. Baker RW, Walker BR, Honour J, et al. Increased cortisol:cortisone ratio in acute pulmonary tuberculosis. Am J Resp Crit Care Med 2000; 162: $1641-1647$.

191. Escher G, Galli E, Vishwanath BS, Frey B, Frey FJ. Tumour necrosis factor $\alpha$ and interleukin $1 \beta$ (enhance the cortisone/cortisol shuttle. J Exp Med 1997; 186: $189-198$.

192. Suzuki T, Sasano H, Suzuki S, et al. 11ßhydroxysteroid dehydrogenase type 2 in human lung: possible regulator of mineralocorticoid action. J Clin Endocrinol Metab 1998; 83: 4022 - 4025.

193. Grange JM. Complications of bacille CalmetteGuerin (BCG) vaccination and immunotherapy and their management. Commun Dis Public Health 1998; 1: $84-88$.

194. Fine PEM. Immunities in and to tuberculosis: implications for pathogenesis and vaccination. In: McAdam KPWJ, Porter JDH, eds. Tuberculosis: back to the future. Proceedings of the London School of Hygiene and Tropical Medicine 3rd Annual Public Health Forum. Chichester: John Wiley, 1993: 54-78.

195. Power CA, Wei G, Bretscher PA. Mycobacterial dose defines the Th1/Th2 nature of the immune response independently of whether immunization is administered by the intravenous, subcutaneous, or intradermal route. Infect Immun 1998; 66: 5743-5750.

196. Griffin JF, Mackintosh CG, Slobbe L, Thomson AJ, Buchan GS. Vaccine protocols to optimise the protective efficacy of BCG. Tuber Lung Dis 1999; 79: $135-143$.

197. Lowry PW, Ludwig TS, Adams JA, et al. Cellular immune responses to four doses of percutaneous bacille Calmette-Guerin in healthy adults. $J$ Infect Dis 1998; 178: $138-146$.

198. Das SD, Narayanan PR, Kolappan C, Colston MJ. The cytokine response to bacille Calmette Guerin vaccination in South India. Int $J$ Tuberc Lung Dis 1998; 2: 836-843.

199. Krieg AM, Hartmann G, Yi AK. Mechanism of action of CpG DNA. Curr Top Microbiol Immunol 2000; 247: $1-21$.

200. Kamath AT, Feng CG, Macdonald M, Briscoe H, Britton WJ. Differential protective efficacy of DNA vaccines expressing secreted proteins of Mycobacterium tuberculosis. Infect Immun 1999; 67: $1702-1707$.

201. Hess J, Grode L, Hellwig J, et al. Protection against murine tuberculosis by an attenuated recombinant Salmonella typhimurium vaccine strain that secretes 
the 30-kDa antigen of Mycobacterium bovis BCG. Fems Immunol Med Microbiol 2000; 27: 283-289.

202. Morris S, Kelley C, Howard A, Li Z, Collins F. The immunogenicity of single and combination DNA vaccines against tuberculosis. Vaccine 2000; 18: $2155-2163$

203. Ulrichs T, Munk ME, Mollenkopf $\mathrm{H}$, et al. Differential $\mathrm{T}$ cell responses to Mycobacterium tuberculosis ESAT6 in tuberculosis patients and healthy donors [published erratum appears in Eur J Immunol 1999 Feb;29(2):725]. Eur J Immunol 1998; 28: $3949-3958$.

204. Brandt L, Elhay M, Rosenkrands I, Lindblad EB, Andersen P. ESAT-6 subunit vaccination against Mycobacterium tuberculosis. Infect Immun 2000; 68: $791-795$.

205. Oftung F, Borka E, Kvalheim G, Mustafa AS. Mycobacterial crossreactivity of $M$. tuberculosis reactive $\mathrm{T}$ cell clones from naturally converted $\mathrm{PPD}$ positive healthy subjects. Fems Immunol Med Microbiol 1998; 20: 231-238.

206. Fine PEM, Ponnighaus JM, Maine N, Clarkson JA, Bliss L. The protective efficacy of BCG against leprosy in Northern Malawi. Lancet 1986; ii: 499-502.

207. Fine PE, Sterne JAC, Ponnighaus JM, Rees RJW. Delayed type hypersensitivity, mycobacterial vaccines and protective immunity. Lancet 1994; 344: $1245-$ 1249

208. Kardjito T, Beck JS, Grange JM, Stanford JL. A comparison of the responsiveness to four new tuberculins among Indonesian patients with pulmonary tuberculosis and healthy subjects. Eur J Respir Dis 1986; 69: 142 - 145.

209. Silva CL, Lowrie DB. A single mycobacterial protein (hsp65) expressed by a transgenic antigen-presenting cell vaccinates mice against tuberculosis. Immunology 1994; 82: $244-248$.

210. Turner OC, Roberts AD, Frank AA, et al. Lack of Protection in Mice and Necrotizing Bronchointerstitial Pneumonia with Bronchiolitis in Guinea Pigs Immunized with Vaccines Directed against the hsp60 Molecule of Mycobacterium tuberculosis. Infect Immun 2000; 68: 3674-3679.

211. Young DB. Heat-shock proteins: immunity and autoimmunity. Curr Opin Immunol 1992; 4: 396400.

212. Chen CH, Wang TL, Hung CF, et al. Enhancement of DNA vaccine potency by linkage of antigen gene to an HSP70 gene. Cancer Res 2000; 60: 1035-1042.

213. Belles C, Kuhl A, Nosheny R, Carding SR. Plasma membrane expression of heat shock protein 60 in vivo in response to infection. Infect Immun 1999; 67: 4191 4200

214. Stanford JL, Onyebujoh PC, Rook GAW, Grange JM, Pozniak A. Old plague, new plague and a treatment for both? AIDS 1993; 7: 1275-1277.

215. Holland SM. Cytokine therapy of mycobacterial infections. Adv Intern Med 2000; 45: 431-452.

216. Hernandez-Pando R, Pavon L, Orozco EH, Rangel J, Rook GAW. Interactions between hormone-mediated and vaccine-mediated immunotherapy for pulmonary tuberculosis in Balb/c mice. Immunology 2000; 100: $391-398$.

217. Turner J, Rhoades ER, Keen M, Belisle JT, Frank AA, Orme IM. Effective preexposure tuberculosis vaccines fail to protect when they are given in an immunotherapeutic mode. Infect Immun 2000; 68: $1706-1709$.

218. Rook GAW, Hernandez-Pando R. The pathogenesis of tuberculosis. Annu Rev Microbiol 1996; 50: $259-$ 284.

219. Lowrie DB, Tascon RE, Bonato VL, et al. Therapy of tuberculosis in mice by DNA vaccination. Nature 1999; 400: 269-271.

220. Group DIT. Immunotherapy with Mycobacterium vaccae in patients with newly diagnosed pulmonary tuberculosis: a randomised controlled trial. Lancet 1999; 354: 116-119.

221. Johnson JL, Kamya RM, Okwera A, et al. Randomised controlled trial of Mycobacterium vaccae immunotherapy in non human immunodeficiency virus infected Ugandan adults with newly diagnosed pulmonary tuberculosis. J Infect Dis 2000; 181: In press.

222. Etemadi A, Farid R, Stanford JL. Immunotherapy for drug resistant tuberculosis. Lancet 1992; 340: 1360 1361.

223. Abou-Zeid C, Gares MP, Inwald J, et al. Induction of a type 1 immune responses to a recombinant antigen from Mycobacterium tuberculosis expressed in Mycobacterium vaccae. Infect Immun 1997; 65: $1856-1862$.

224. Skinner MA, Yuan S, Prestidge R, Chuk D, Watson JD, Tan PLJ. Immunization with heat-killed Mycobacterium vaccae stimulates CD8 + cytotoxic $\mathrm{T}$ cells specific for macrophages infected with Mycobacterium tuberculosis. Infect Immun 1997; 65: $4525-4530$.

225. Wang CC, Rook GAW. Inhibition of an established allergic response to ovalbumin in Balb/c mice by killed Mycobacterium vaccae. Immunology 1998; 93: 307 313

226. Camporota L, Corkhill A, Long $\mathrm{H}$, et al. Effects of intradermal Mycobacterium vaccae on allergeninduced airway responses and IL-5 generation by PBMC in mild to moderate asthma. Am J Respir Crit Care Med 2000; 161: 477.

227. Waddell RD, Chintu C, Lein AD, et al. Safety and immunogenicity of a five-dose series of inactivated Mycobacterium vaccae vaccine for the prevention of HIV-associated tuberculosis. Clin Infect Dis 2000; 30: Suppl. S309-315.

228. Grange JM, Laszlo A. Serodiagnostic tests for tuberculosis: a need for assessment of their operational predictive accuracy and acceptability. Bull World Health Organ 1990; 68: 571-576.

229. Skjot RL, Oettinger T, Rosenkrands I, et al. Comparative evaluation of low-molecular-mass proteins from Mycobacterium tuberculosis identifies members of the ESAT-6 family as immunodominant T-cell antigens. Infect Immun 2000; 68: 214-220.

230. Cole ST, Brosch R, Parkhill J, et al. Deciphering the biology of Mycobacterium tuberculosis from the complete genome sequence [published erratum appears in Nature 1998 Nov 12; 396(6707):190]. Nature 1998; 393: $537-544$.

231. Manabe YC, Dannenberg AJ, Bishai WR. What we can learn from the Mycobacterium tuberculosis genome sequencing projects [In Process Citation]. Int J Tuberc Lung Dis 2000; S18-23.

232. Gomez M, Johnson S, Gennaro ML. Identification of secreted proteins of mycobacterium tuberculosis by a 
bioinformatic approach. Infect Immun 2000; 68: 2323 2327.

233. Behr MA, Wilson MA, Gill WP, et al. Comparative genomics of BCG vaccines by whole-genome DNA microarray. Science 1999; 284: 1520-1523.

234. Wilson M, DeRisi J, Kristensen HH, et al. Exploring drug-induced alterations in gene expression in
Mycobacterium tuberculosis by microarray hybridization. Proc Natl Acad Sci USA 1999; 96: 12833 - 12838. 235. Rook GAW, Stanford JL. Give us this day our daily germs. Immunology Today 1998; 19: 113-116.

236. Ristori G, Buzzi MG, Sabatini U, et al. Use of Bacille Calmette-Guerin (BCG) in multiple sclerosis. Neurology 1999; 53: 1588-1589. 